\title{
Does Efficiency Help Banks Survive and Thrive during Financial Crises?*
}

\author{
Albert Assaf $^{\text {a }}$, Allen N. Berger ${ }^{b, c, d, \dagger}$, Raluca A. Roman ${ }^{e}$, Mike Tsionas $^{f}$ \\ ${ }^{a}$ University of Massachusetts-Amherst, Amherst, MA 01003 USA \\ ${ }^{b}$ University of South Carolina, Columbia, SC 29208 USA \\ ${ }^{c}$ Wharton Financial Institutions Center, Philadelphia, PA 19104 USA \\ ${ }^{d}$ European Banking Center, Tilburg, the Netherlands \\ ${ }^{e}$ Federal Reserve Bank of Philadelphia, Philadelphia, PA 19106 USA \\ ${ }^{f}$ Lancaster University, Lancaster. LA1 4YW, UK
}

July 2019

\begin{abstract}
We examine how bank efficiency during normal times affects survival, risk, and profitability during subsequent financial crises using data from five U.S. financial crises and preceding normal times. We find cost efficiency during normal times helps reduce bank failure probabilities, decrease risk, and enhance profitability during subsequent financial crises, while profit efficiency has limited benefits. Results suggest that cost efficiency better measures management quality, while profit efficiency may partially reflect temporary high returns from risky investments during normal times. Findings have policy implications and imply that improving bank cost efficiency during normal times may promote better financial crisis performance.
\end{abstract}

Keywords: Banking, Efficiency, Financial Crises, Performance, Survival, Risk, Profitability JEL Classification Codes: G18, G21, G28

\footnotetext{
* The views expressed are those of the authors and do not represent the views of the Federal Reserve Bank of Philadelphia City or the Federal Reserve System. The authors thank the anonymous referees, Ivan Lim (discussant), Laurent Well (discussant), Tony Saunders, Larry White, and participants at the presentations at the Financial Management Association and Southern Finance Association Meetings for useful comments and suggestions.

Email addresses: assaf@isenberg.umass.edu (Albert Assaf), aberger@moore.sc.edu, (Allen N. Berger), raluca.roman@phil.frb.org (Raluca A.Roman), m.tsionas@lancaster.ac.uk, (Mike Tsionas).

${ }^{\dagger}$ Corresponding Author. Moore School of Business, University of South Carolina, 1014 Greene Street, Columbia, SC 29208, E-mail: aberger@moore.sc.edu.
} 
Regulators agree that "the worst loans are made at the top of the business cycle." (Alan Greenspan, Chicago Bank Structure Conference May 10, 2001)

"Historically, the goals of banking regulation have included...the promotion of competition and efficiency in banking..." (Ben Bernanke, Bank Regulation and Supervision: Balancing Benefits and Costs, 2006)

\section{Introduction}

Financial crises are very costly for the real economy. ${ }^{1}$ Much of the costs come from the banking industry. Bank failures and performance problems often result in significant negative externalities for other connected financial institutions, borrowers, creditors, and other parties in the real economy that depend on credit and other services from the failed and distressed institutions, as well as governments that frequently get involved in costly bailouts of these banks (e.g., Barth, Bartholomew, and Bradley, 1990; James, 1991; Lang and Stulz, 1992; Ashcraft, 2005; Reinhart and Rogoff, 2009; Acharya, Cooley, Richardson, and Walter, 2011; Laeven and Valencia, 2012; Kupiec and Ramirez, 2013; Kang, Lowery, and Wardlaw, 2014). Thus, it is critical to understand the major determinants of bank performance during financial crises to tailor public policies, regulations, and management practices to detect and reduce the occurrence of bank problems early.

As noted in one of the quotes above, bank problems during crises are frequently the result of bad decisions made during the normal times that precede them (Greenspan, 2001). One important reason may be institutional memory loss. When bank problems have not been prevalent for some time, bank loan officers and managers may suffer atrophy in their abilities to recognize and deal with such problems (e.g., Berger and Udell, 2004). It is therefore logical to look to the normal times that precede financial crises to discover the determinants of bank performance during these crises. The extant literature on the determinants of bank performance generally focuses on the time periods immediately previous to this performance, irrespective of whether these are crisis or normal times. This paper extends the literature by examining the determinants of bank crisis performance in terms of survival, risk, and profitability by focusing on the

\footnotetext{
${ }^{1}$ To illustrate, the subprime financial crisis of the late 2000s is estimated to have cost the U.S. economy in the range of $\$ 12$ trillion-\$22 trillion, although many of the economic costs remain difficult to determine (U.S. Department of the Treasury, 2012; Atkinson, Luttrell, and Rosenblum, 2013; Government Accountability Office, 2013; Garcia, 2015).
} 
preceding normal time periods, when the problems that are manifested during the crises most likely originated.

The literature on bank performance during crises is also generally limited in the factors that are examined. The focus is usually on accounting variables such as capital, liquidity, profitability, and loan quality (e.g., Lane, Looney, and Wansley, 1986; Espahbodi, 1991; Cole and Gunther, 1995, 1998; Helwege, 1996; Wheelock and Wilson, 1995, 2000; Calomiris and Mason, 1997, 2003; Molina, 2002; Elsinger, Lehar, and Summer, 2006; Schaeck, 2008; Admati, DeMarzo, Hellwig, and Pfleiderer, 2011; Cole and White, 2012; Knaup and Wagner, 2012; Berger and Bouwman, 2013; Hong, Huang, and Wu, 2014; Berger, Imbierowicz, and Rauch, 2016), the scope of bank activities (investment banking, private equity, new financial products (e.g., Cole and White, 2012; DeYoung and Torna, 2013), bank ownership and corporate governance (e.g., Giannetti and Ongena, 2009; Fahlenbrach and Stulz, 2011; Berger and Bouwman, 2013; Berger, Imbierowicz, and Rauch, 2016; Calomiris and Carlson, 2017), and regional economic conditions (e.g., Aubuchon and Wheelock, 2010).

An overlooked factor affecting bank performance during crises is bank efficiency in the normal times prior to the crises. Researchers often study the effects of bank efficiency on bank performance (e.g., Cebenoyan, Cooperman, Register, and Hudgins 1993; Hermalin and Wallace, 1994; Berger and Mester, 1997; Fiordelisi, Marques-Ibanez, and Molyneux 2011; Hughes and Mester, 2015), but none examine the effects of efficiency during normal times on performance during subsequent crises.

The closest paper in approach to ours is Berger and Bouwman (2013), who focus on the effects of capital during eight quarters of normal times prior to financial crises on bank survival and market share outcomes during the subsequent crises. Our contribution is quite different from theirs in that we focus on cost and profit efficiency as potential determinants of bank outcomes, controlling for bank capital and other factors included in the literature. In addition, while Berger and Bouwman (2013) include pre-crisis profitability as a control variable, we focus on profit efficiency. Profit efficiency nets out the effects of 
product mix, variable input prices, fixed inputs and outputs, environmental factors, and random error.

We evaluate the effects of both normal-times cost and profit efficiency on bank performance because cost and profit efficiency measure different concepts and may affect future outcomes through different channels. Cost efficiency measures the proximity of a bank's cost to that of a best-practice or most efficient bank producing the same output that faced the same input prices and environmental conditions. Profit efficiency is the more general concept that includes revenues as well as costs. Profit efficiency measures the proximity of bank profits to those of a best-practice or most efficient bank under the same conditions. The "alternative profit efficiency" measure we employ is based on how much a bank earns relative to what would be earned by a best-practice bank that produced the same output and faced the same input prices and environmental conditions. Our findings for the two types of efficiency are very different, justifying our separate treatment.

At first blush, cost and profit efficiency may seem to unconditionally lead to better future bank outcomes, but the reality is more complex. In fact, relatively high cost and profit efficiency during normal times can result in either favorable or unfavorable performance during subsequent financial crises. High cost efficiency in normal times may reflect superior managerial quality that endures through the following crisis and produces favorable performance. Alternatively, high cost efficiency during normal times may reflect "skimping" on resources to screen and monitor loan applicants, which saves resources during normal times, but creates poor loan outcomes that become apparent only during subsequent financial crises (e.g., Berger and DeYoung, 1997). Both of these channels may also apply to profit efficiency, which encompasses costs as well as revenues.

Additional channels may apply to profit efficiency. High profit efficiency may be associated with high charter values that result in favorable performance during subsequent financial crises because bank act to preserve these charter values. Alternatively, high profit efficiency during normal times may reflect excessive risk taking that earns high returns in normal times, but creates problems in subsequent crises. 
Based on these channels, we formulate and test hypotheses for the effects of both cost and profit efficiency during normal times on bank failure, risk, and profitability during subsequent financial crises. The data include virtually all U.S. banks from five financial crises originally classified by Berger and Bouwman (2013), and their pre-crisis normal time periods - a total of 15,993 banks over the interval from 1986:Q1 to 2009:Q4. We include multiple financial crises and normal time periods to draw general conclusions and minimize the impact of idiosyncratic circumstances of a single crisis. The grouping of crises in the analysis is also helpful because it is never known in advance what type of crisis may be coming next, so our results can help bank stakeholders prepare for a multiplicity of eventualities.

We find that cost efficiency during normal times reduces failure probabilities, decreases risk, and enhances profitability during subsequent financial crises, while profit efficiency has limited benefits. These findings suggest that cost efficiency may proxy well for management quality, while profit efficiency may partially reflect temporary high returns during normal times from risky investments. Our results suggest that bank stakeholders - including policymakers, regulators, supervisors, owners, creditors, and managers - may consider monitoring more closely banks with low cost efficiency during normal times so as to reduce the occurrence of costly bank problems during financial crises. In addition, managerial policies and procedures that promote cost efficiency, which could improve performance during subsequent crises. Our findings also suggest that researchers consider putting more trust in cost efficiency as an indicator of bank quality than profit efficiency.

We perform a variety of robustness checks. First, we test the sensitivity of our results to using alternative measures of bank performance. Second, we run the regressions separately for banking and market crises, those that originated in the banking sector and in financial markets, respectively. Third, we exclude banks that may be too-big-to-fail (TBTF) to mitigate the potential concern that our results may be driven by such banks. Fourth, we run tests when controlling for a simpler measure of efficiency used in the literature, total bank costs to total bank revenues (cost-to-income). Fifth, we consider alternative pre-crisis periods, measuring efficiency and control variables over the four quarters before a crisis instead of the full 
pre-crisis time period. Sixth, we consider the effects of efficiency on small versus large banks. Finally, we run tests which allow for the possibility of nonlinear relations between efficiency and the bank performance. Our main findings stand up to all of these robustness checks.

The remainder of the paper is organized as follows. Section 2 discusses the cost and profit efficiency concepts and measurement. Section 3 describes the channels through which normal-times bank cost and profit efficiency may influence subsequent financial crisis performance and develops opposing hypotheses from these channels. Section 4 discusses our empirical framework - it gives our approach, describes the financial crises and normal times, and explains the regression models and key bank performance variables. Section 5 displays the data sample and sources. Section 6 reports reviews the summary statistics and presents our main regression results. Section 7 discusses robustness checks and Section 8 provides a deeper analysis of our cost efficiency results. Section 9 concludes.

\section{Cost and Profit Efficiency Concepts and Measurement}

\subsection{Cost and Profit Efficiency Concepts}

Banks often pursue the economic goals of cost minimization and/or profit maximization. Researchers for the last three decades measure how well banks achieve these goals through the concepts of cost efficiency and profit efficiency. The cost efficiency of a bank tells us how close a bank's cost is to what a best-practice bank's cost for producing the same current level of output under the same conditions. It is measured by the ratio of the minimum cost a best-practice bank would incur to the bank's actual cost if the two banks produced the same output quantities and faced the same conditions (same input prices and environmental conditions).

Conversely, the profit efficiency of the bank tells us how close a bank is to producing the maximum possible profit of a best-practice banks under the same conditions. It is measured as the ratio of a bank's actual profit earned to the maximum profit a best-practice bank would attain for the same input prices, environmental conditions, and either output prices or quantities (e.g., Mullineaux, 1978; Berger, Hancock, 
and Humphrey, 1993; Soteriou and Zenios, 1999; Maudos, Pastor, Perez, and Quesada, 2002). Profit efficiency is a broader concept than cost efficiency because the profit function allows for consideration of revenues as well as costs.

For our purposes in this paper, we take output quantities, rather than output prices as given, and measure "alternative profit efficiency." As discussed in Berger and Mester (1997), alternative profit efficiency is preferred as it provides additional information when some of the assumptions required by standard profit efficiency - relatively homogeneous output quality, easily-changed output quantities, highly competitive output markets, and well-measured output prices - do not hold. Because of the inherent benefits, most bank profit efficiency papers over the past 20 years use alternative profit efficiency (e.g., Vander Vennet, 2002; Restrepo-Tobon and Kumbhakar, 2014; Wheelock and Wilson, 2016).

It might be expected that bank managers would always strive for both high cost and profit efficiency, that the two measures would be strongly positively correlated, and that both would predict favorable future outcomes, but the reality is more complex. Cost and profit efficiency may not be strongly positively related because bank outputs have quality differences that are difficult to measure. Higher-quality services may require higher costs and result in lower measured cost efficiency, but fetch higher output prices that result in higher profits and measured profit efficiency (e.g., Berger and Mester, 1997; Lozano-Vivas, 1997; Rogers, 1998; Maudos, Pastor, Perez, and Quesada, 2002). Bank outputs may also have different risk characteristics that are challenging to measure. Higher-risk outputs typically have higher expected returns, which may boost profit efficiency during normal times and may not have favorable effects on cost efficiency. As discussed in Section 3, high cost and profit efficiency during normal times may predict either favorable or unfavorable bank performance during subsequent financial crises, depending on the relative importance of several different channels.

\subsection{Efficiency Measurement}

We measure both cost and profit efficiency for every bank for every quarter of the normal times periods, 
and use statistics computed over all the quarters of these periods to reduce the impact of outliers.

\subsubsection{Variables Included in the Cost and Alternative Profit Functions}

The first step in computing efficiency is the choice of variables specified in the cost and alternative profit functions. We define total costs as total interest expenses plus total noninterest expenses, and total profits as total bank net income. We specify four input prices: $w_{1}$, price of labor (ratio of total personnel expenses to number of employees); $w_{2}$, price of physical capital (total operating and administrative expenses to total premises and fixed assets); $w_{3}$, price of purchased funds ((total interest expenses - total interest on core deposits)/(quantity of total liabilities - core deposits)); and $w_{4}$, price of core deposits ((total interest on deposits - interest on time deposits over $\$ 100,000) /$ quantity of core deposits). ${ }^{2}$ We use the following five output quantities: $y_{1}$, consumer loans; $y_{2}$, commercial and industrial (C\&I) loans; $y_{3}$, residential real estate (RRE) loans (1-4 family); $y_{4}$, commercial real estate (CRE) loans (total real estate loans - RRE loans); $y_{5}$, other loans (total loans $\left.-\left(y_{1}+y_{2}+y_{3}+y_{4}\right)\right)$. We also include quantities of two fixed netputs (inputs or outputs): $z_{1}$, the notional value of total bank off-balance sheet activities; and $z_{2}$, bank financial equity capital. $^{3}$ Finally, we include an environmental variable to account for the risk exposure of the bank, $v$, the weighted nonperforming loan ratio of all banks in the bank's state, where the weights are based on the

${ }^{2}$ Complete data for the input prices $w_{3}$ and $w_{4}$ are not available in the Call Report prior to 1997 due to insufficient information on the core deposits. Therefore, we calculate an average ratio of core deposits to total deposits for each bank over the periods that data are available. We assume that the bank uses the same ratio in the earlier time periods where we cannot determine this based on the Call Report (1986:Q1 - 1996:Q4). If for a bank we cannot compute the ratio described as no reports are available, we use the industry ratio average by size class.

${ }^{3}$ In choosing outputs, we focus on modern banking theories in which banks intermediate deposits into loans and also engage in off-balance sheet activities. Under many of these theories, banks are special because they screen and monitor on-balance sheet loans and off-balance sheet loan commitments and similar claims to liquid funds (e.g., Diamond, 1984; Ramakrishnan and Thakor, 1984; Boyd and Prescott, 1986; James, 1987). We specifically exclude other earning assets or securities as outputs, since these are methods of storing liquidity for banks so that they might have funds available to make future loans or respond to liquidity shocks from liabilities or off-balance sheet activities. Under other recent theories of bank liquidity creation, securities actually subtract from banking output, and they receive negative weights in liquidity creation empirical measures (e.g., Bryant, 1980; Diamond and Dybvig, 1983; Berger and Bouwman, 2009). Thus, under these theories, securities are better thought of as inputs to the banking functions rather than outputs. 
proportions of deposits of the banks in the state. ${ }^{4}$

\subsubsection{Specification of the Cost and Alternative Profit Functions}

We use the Fourier-flexible functional form for the cost and alternative profit functions to estimate bankspecific efficiency measures, which are used subsequently in panel estimations of effects of bank efficiency on bank performance. Prior research shows that the Fourier-flexible form is preferable to functional forms based on second-order Taylor series expansions, such as the translog or normalized quadratic (e.g., Gallant, 1981, 1982; Berger and Mester, 1997). The Fourier-flexible form incorporates the translog and augments it by including Fourier trigonometric terms, so it is more flexible than the translog, and is a global approximation to virtually any cost or profit function. In addition, many researchers found that it fits the data for U.S. banks better than other functional forms (e.g., McAllister and McManus, 1993; Mitchell and Onvural, 1996). For the cost function, we specify:

$$
\begin{aligned}
\ln \left(C / w_{4} z_{2}\right)= & \delta+\sum_{i=1}^{3} \beta_{i} \ln \left(w_{i} / w_{4}\right)+\frac{1}{2} \sum_{i=1}^{3} \sum_{j=1}^{3} \beta_{i j} \ln \left(w_{i} / w_{4}\right) \ln \left(w_{i} / w_{4}\right)+\sum_{k=1}^{5} \gamma_{k} \ln \left(y_{k} / z_{2}\right) \\
& +\frac{1}{2} \sum_{k=1}^{5} \sum_{m=1}^{5} \gamma_{k m} \ln \left(y_{k} / z_{2}\right) \ln \left(y_{m} / z_{2}\right)+\delta_{1} \ln \left(z_{1} / z_{2}\right)+\frac{1}{2} \delta_{11} \ln \left(z_{1} / z_{2}\right) \ln \left(z_{1} / z_{2}\right) \\
& +\sum_{i=1}^{3} \sum_{k=1}^{5} \eta_{i k} \ln \left(w_{i} / w_{4}\right) \ln \left(y_{k} / z_{2}\right)+\sum_{i=1}^{3} \rho_{i} \ln \left(w_{i} / w_{4}\right) \ln \left(z_{1} / z_{2}\right) \\
& +\sum_{k=1}^{5} \tau_{k} \ln \left(y_{k} / z_{2}\right) \ln \left(z_{1} / z_{2}\right)+\sum_{n=1}^{9}\left[\phi_{n} \cos \left(x_{n}\right)+\omega_{n} \sin \left(x_{n}\right)\right] \\
& +\sum_{n=1}^{9} \sum_{q=n}^{9}\left[\phi_{n q} \cos \left(x_{n}+x_{q}\right)+\omega_{n q} \sin \left(x_{n}+x_{q}\right)\right] \\
& +\sum_{n, n^{\prime}, n^{\prime \prime}=1}^{9}\left[\phi_{n n^{\prime} n^{\prime \prime}} \cos \left(x_{n}+x_{n^{\prime}}+x_{n^{\prime \prime}}\right)+\omega_{n n n} \sin \left(x_{n}+x_{n^{\prime}}+x_{n^{\prime \prime}}\right)\right]+\varsigma_{1} \ln v+\ln u_{c}+\ln \varepsilon_{c}
\end{aligned}
$$

\footnotetext{
${ }^{4}$ A small minority of banks are in multiple states. Since we only know the location of deposits from the Summary of Deposits data for these banks, we allocate nonperforming loans proportionately to the states according to the location of their deposits.
} 
where $\left(y_{k} / z_{2}\right)$ and $\left(z_{1} / z_{2}\right)$ have one added to avoid taking the natural log of zero, the $x_{n}$ 's are rescaled terms of the $\ln \left(w_{i} / w_{4}\right), \ln \left(y_{k} / z_{2}\right)$, and $\ln \left(z_{1} / z_{2}\right)$, so that each of the $x_{n}$ lies in the interval $[0,2 \pi]$, where $\pi$ indicates radians (rather than profits as below). ${ }^{5}$ We apply the standard symmetry restrictions to the translog part of the function (i.e., $\beta_{i j}=\beta_{j i}, \gamma_{k m}=\gamma_{m k}$ ). In the composed error term, $\ln \varepsilon_{\mathrm{c}}$ represents noise and $\ln u_{c}$ represents cost inefficiency.

The alternative profit function requires a few changes. The dependent variable is $\ln \left[\left(\pi / w_{4} z_{2}\right)+\left|\left(\pi / w_{4} z_{2}\right)^{\min }\right|+1\right]$, where $\left|\left(\pi / w_{4} z_{2}\right)^{\min }\right|$ indicates that the absolute value of the minimum value of normalized profit, and the $\left|\left(\pi / w_{4} z_{2}\right)^{\mathrm{min}}\right|+1$ is added so we can take the natural log of a positive number, since minimum profits are usually negative. The composed error is $\ln u_{\pi}+\ln \varepsilon_{\pi}$.

As shown above, we normalize the cost, profit, and input price terms by the last input price $w_{4}$ to ensure linear homogeneity, and normalize cost, profit, output quantities, and fixed netput quantities by the last fixed netput financial equity capital $z_{2}$. These normalizations are fairly standard in the cost and profit function literature. Normalizing by one input price in the Fourier-flexible functional form is the only way to ensure linear homogeneity, so that doubling all input prices exactly doubles costs on the efficient frontier. Normalization by a fixed netput makes sure that the banks are treated comparably and not subject to scale bias - otherwise the large banks would dominate the regressions. Normalization by equity helps with economic interpretation of the profit function, given that the dependent variable is proportional to profits per dollar of equity, or return on equity.

5 Following Berger and Mester (1997), we cut $10 \%$ off each end of the $[0,2 \pi]$ interval so that the $x_{n}$ span $[0.1 \times 2 \pi, 0.9 \times 2 \pi]$ to reduce approximation problems near the endpoints. The formula for $x_{n}$ is $(0.2 \times \pi-\mu \times a+\mu \times$ variable $)$, where $[a, b]$ is the range of the variable being transformed and $\mu \equiv(0.9 \times 2 \pi-0.1 \times 2 \pi) /(b-a)$. 


\subsubsection{Measuring Efficiency from the Estimated Cost and Alternative Profit Functions}

The key to measuring efficiency is disentangling inefficiency $\ln u$, from random error $\ln \varepsilon$. Since we have a number of time periods, our preferred method for the estimation of efficiency is the distribution-free approach, which disentangles them by assuming that inefficiencies are relatively stable and random errors tend to average out to zero over time (Berger, 1993).

We estimate the cost and alternative profit functions separately for each quarter of a normal-times interval to account for possible changes over time in technology, regulation, and external environment. We then average the residuals over all the quarters of the normal-times period to obtain preliminary estimates of the inefficiency term $\ln u$ for each bank, effectively assuming that the random error $\ln \varepsilon$ averages out to zero over time. To avoid the impact of extreme values, we follow Berger and Mester (1997) and winsorize the extreme values. Specifically, those banks in the top and bottom 5\% are assigned values of banks at the $95^{\text {th }}$ and $5^{\text {th }}$ percentiles, respectively. ${ }^{6}$ Cost efficiency for each bank and each quarter is estimated as the ratio of minimum predicted cost for that bank to the actual predicted costs. The minimum predicted cost for the bank uses the values of the cost function arguments for that bank and the minimum cost function truncated average residual for the sample. The actual predicted costs for the bank also use the values of the cost function for that bank combined with the truncated average residual for the bank.

These cost efficiencies are then ranked for each quarter in descending order of efficiency, so that a bank that is more efficient than $80 \%$ of the observations for that quarter is assigned a 0.80 cost efficiency rank for that quarter. We then average the ranks over all the quarters of the normal-times period to obtain a comparable measure to use in our regression models of bank performance in the subsequent financial crisis. We prefer efficiency ranks to levels because ranks remove changes in the distributions of efficiency over time that are not relevant to our hypotheses. Average profit efficiency ranks are determined in similar fashion, except that they are based on the ratio of actual predicted profit for that bank to the maximum

\footnotetext{
${ }^{6}$ Our results are robust when we alternatively winsorize at $2.5 \%$ and $97.5 \%$ levels and at $1 \%$ and $99 \%$ levels.
} 
predicted profit. ${ }^{7}$

\section{Hypothesis Development}

We next discuss channels through which normal-times bank cost and profit efficiency may affect likelihood of failure, risk, and profitability of banks during subsequent financial crises, and form hypotheses from these channels. Section 3.1 describes the cost efficiency channels, Section 3.2 explains the profit efficiency channels, and Section 3.3 gives the resulting hypotheses.

\subsection{Channels for Bank Cost Efficiency}

High cost efficiency during normal times can have either favorable or unfavorable effects on bank performance during subsequent financial crises. The favorable effects go through the following channel:

- Good management channel: If management that is proficient at keeping costs down during normal times is also proficient at managing portfolios, then high cost efficiency may be associated with lower likelihood of bank failure, lower risk, and greater profitability during subsequent financial crises (e.g., Berger and DeYoung, 1997; Kwan and Eisenbeis, 1997; Williams, 2004).

The unfavorable effects of high cost efficiency operate through the following alternative channel:

- Skimping channel: Banks may achieve high cost efficiency during normal times by devoting relatively few resources to screening and monitoring loan applicants. This "skimping" channel, introduced by Berger and DeYoung (1997), improves cost efficiency during normal times and may not be noticed because the resulting poor loan performance only becomes apparent during subsequent financial crises.

\footnotetext{
${ }^{7}$ We do not include bank fixed effects in the cost and profit function estimations because these regressions are estimated quarterly and have only one bank observation per quarter. However, our efficiency estimation methods that are based on averaging the residuals may be thought of as similar to bank fixed effects.
} 


\subsection{Channels for Bank Profit Efficiency}

Profit efficiency may operate through the same two channels as cost efficiency because profit efficiency includes the effects of costs as well as revenues. Thus, the good management channel may also apply to profit efficiency because good cost managers are not expected to be significantly worse at managing revenues. Similarly, the skimping channel may also apply to profit efficiency as long as revenues during normal times are not significantly adversely affected by skimping. This may occur because even poor loans may perform well outside of crisis periods.

There are two additional channels through which profit efficiency during normal times may favorably or unfavorably affect financial crisis performance. The additional favorable effects go through the following channel:

- Charter value channel: A bank with high profit efficiency may be expected to have relatively high future profits, and therefore greater charter value. It is often found that banks with greater charter value due to a different source, market power, behave more prudently to protect this value (e.g., Marcus 1984, Keeley 1990, Demsetz, Saidenberg, and Strahan 1996, Hellmann, Murdock, and Stiglitz 2000, Carletti and Hartmann 2003, Jimenez, Lopez, and Saurina 2013). The same logic applies to high profit efficiency, since banks with high profit efficiency are generally more profitable. Thus, banks with high normal-times profit efficiency may behave more prudently and be more likely to survive, have relatively low risk, and relatively high profits during subsequent financial crises.

The additional unfavorable effects go through the following channel:

- $\quad$ Risk-taking channel: Banks may achieve high profit efficiency during normal times by taking on more risk, since high-risk investments generally have higher returns during normal times. The higher risk-taking during normal times may turn into higher failure probabilities, higher risk, and lower profitability during subsequent crises, when high-risk 
investments generally suffer losses. ${ }^{8}$

\subsection{Hypotheses Derived from the Channels}

These channels imply two opposing hypotheses each for the effects of normal-times bank cost and profit efficiency on performance during subsequent financial crises:

Hypothesis 1a. Higher cost efficiency during normal times results in better performance (lower likelihood of failure, lower risk, and higher profitability) during subsequent financial crises.

Hypothesis 1b. Higher cost efficiency during normal times results in worse performance (higher likelihood of failure, higher risk, and lower profitability) during subsequent financial crises.

Hypothesis 2a. Higher profit efficiency during normal times results in better performance (lower likelihood of failure, lower risk, and higher profitability) during subsequent financial crises.

Hypothesis 2b. Higher profit efficiency during normal times results in worse performance (higher likelihood of failure, higher risk, and lower profitability) during subsequent financial crises.

These hypotheses may apply to different degrees to different sets of banks. Our empirical analysis tests which of Hypotheses $\mathbf{1 a}$ or $\mathbf{1 b}$ and which of $\mathbf{2 a}$ and $\mathbf{2 b}$ empirically dominates the other overall.

\section{Empirical Framework}

\footnotetext{
${ }^{8}$ To illustrate, banks' investments in mortgage-backed securities (MBS) were very profitable during the normal time period prior to the subprime financial crisis, but proved very risky and a significant contributing factor to bank failures and the crisis (e.g., Acharya, Philippon, Richardson, and Roubini, 2009; Acharya and Richardson, 2009; Diamond and Rajan, 2009).
} 
This section explains our empirical approach for the failure, risk, and profitability analyses. It also describes the financial crises and normal times.

\subsection{Empirical Approach and Descriptions of Financial Crises and Normal Times}

Our main approach pools the data to treat financial crises and their preceding normal times as a group. We focus on five crises that occurred between 1986:Q1 and 2009:Q4, which were created by Berger

and Bouwman (2013). They include two banking crises (crises that originated in the banking sector) and three market crises (originated outside banking in the financial markets). The banking crises are the credit crunch of the early 1990s (1990:Q1-1992:Q4) and the subprime lending crisis (2007:Q3-2009:Q4). The market crises are the 1987 stock market crash (1987:Q4); the Russian debt crisis and Long-Term Capital Management (LTCM) bailout of 1998 (1998:Q3-1998:Q4); and the bursting of the dot.com bubble and the September 11 terrorist attacks of the early 2000s (2000:Q2-2002:Q3). Normal times include all the quarters since previous crisis, except the first normal times period begins at the start of the data set. The financial crises and normal times are graphed in Figure 1. As discussed above, in our main analysis, we include all the crises in order to draw general conclusions and because it is never known which type of crisis is coming next.

Thus, for the full sample, we have a five-period panel, in which each period corresponds to a different financial crisis. The dependent variables are measures of performance during the crises, and the explanatory variables are measured during the normal time period preceding these financial crises. We have an unbalanced panel, given that some banks enter the sample later, fail, or are merged out of existence during the sample, with the number of observations for each bank varying between one and five. All dependent and independent variables are averages of the quarterly values over the appropriate crisis or normal time period.

\subsection{Regression Models}

We estimate the following model: 


$$
\begin{aligned}
\text { Performance Indicator }_{i, t}= & f\left(\text { COSTEFF }_{i, P R E-t}, \text { PROFITEFF }_{i, P R E-t},\right. \\
& \text { Other Bank Characteristics } \left.\text { CRRE-t }_{i, \text { Crisi }}, \text { Cr,t }_{i}\right) .
\end{aligned}
$$

Performance Indicator $_{i, t}$ is a measure of bank $i$ 's failure, risk, or profitability during crisis period $t, t \in$

$\{1,2,3,4,5\}$. Specifically, our performance measures are as follows. For failure, we use:

i) FAILED $1_{i, t}$, a dummy equal to one if bank $i$ failed as it was placed under receivership or closed by the Federal Deposit Insurance Corporation (FDIC), given it was unable to meet its obligations to depositors and other stakeholders, ${ }^{9}$ and thus was included in the FDIC failure list, or experienced book-value insolvency or technical default (bank became critically undercapitalized, its equity capitalization fell below $2 \%$ of bank gross total assets $\left.\left(\mathrm{GTA}^{10}\right)\right)^{11}$ in crisis period $t$.

ii) FAILED $2_{i, t}$, a dummy equal to one if bank $i$ failed as it was placed under receivership or closed by the Federal Deposit Insurance Corporation (FDIC), given it was unable to meet its obligations to depositors and other stakeholders, and thus was included in the FDIC failure list in crisis period $t$.

We prefer FAILEDI as our main measure of bank failure, given it is more comprehensive, including bank technical defaults, consistent with other prior research in banking (e.g., Wheelock and Wilson, 1995, 2000; Cole and White, 2012). FAILED2 is also used as an alternative.

\footnotetext{
${ }^{9}$ As receiver, the FDIC has the role to resolve a failed institution in order to maximize the return on the assets of the failed bank and minimize any loss to the deposit insurance fund. To accomplish a resolution, FDIC can 1) merge a failed institution with another insured depository institution and transfer its assets and liabilities, 2) form a new institution, known as a bridge bank, to take over the assets and liabilities of the failed institution, or 3) sell or pledge the assets of the failed institution to the FDIC in its corporate capacity (e.g., FDIC, 2013). The FDIC bank failure list is available at: https://www.fdic.gov/bank/individual/failed/banklist.html.

${ }^{10}$ Gross total assets (GTA) equals total assets plus the allowance for loan and lease losses and the allocated transfer risk reserve (a reserve for certain foreign loans). Total assets on Call Reports deduct these two reserves, which are held to cover potential credit losses. We add these reserves back to measure the full value of the assets financed.

11 This definition of technical default is consistent with the FDIC Improvement Act of 1991, which requires regulators to close or impose prompt corrective actions on any bank whose equity ratio falls below $2 \%$ (critically undercapitalized).
} 
As proxies for risk ${ }^{12}$, we use:

i) $L N(Z S C O R E)_{i, t}$, log of the sum of a bank's mean ROA (net income over GTA) and mean CAPITAL RATIO (equity capital over GTA) divided by $\sigma R O A$ (the volatility of ROA), where the means of the components are calculated over crisis period $t$.

ii) $\sigma_{R O A} i, t$, volatility of return on assets (ROA) of bank $i$ over crisis period $t$.

As proxies for profitability, we use:

i) $R O A_{i, t}$, return on assets (net income over GTA) of bank $i$ averaged over crisis period $t$.

ii) $R O E_{i, t}$, return on equity (net income over capital equity) of bank $i$ averaged over crisis period $t .^{13}$

Equation (2) is run as a logit for the failure variables, and as OLS for the continuous outcome measures. COSTEFF $_{i, P R E-t}$, and $P R O F I T E F F_{i, P R E-t}$ are profit and cost efficiency ranks over the normal time period prior to the financial crisis. Other Bank Characteristics $_{i, P R E-t}$ is a set of control variables averaged over the normal times period. Crisis $s_{i, t}$ is a set of individual crises dummies, which act as time fixed effects. We exclude one crisis dummy to avoid perfect collinearity.

To address potential concerns that error terms may be heteroscedastic or correlated across time periods for each bank, we run all regressions adjusting the standard errors for heteroscedasticity and withinbank clustering.

\section{Data Sample, Sources, and Control Variables}

12 Both risk measures, $L N(Z S C O R E)$ and $\sigma_{R O A}$, cannot be calculated over one of the market crises - the stock market crash of 1987:Q4 - which lasts only one quarter. The statistics and regressions using these measures therefore have smaller numbers of observations than the variables for failure and performance, dropping from 48,532 to 35,151 observations.

13 To address concerns related to differences in performance for banks with potentially different tax treatments (e.g., $\mathrm{S}$ corporations versus $\mathrm{C}$ corporations), we also try using alternative definitions of $R O A$ and $R O E$ that use income before applicable income taxes over GTA and equity capital, respectively. Untabulated results using these alternative definitions are consistent with our main findings. 
This section first explains our data sample and sources, followed by details on the control variables. The key independent variables measuring efficiency are described in Section 2 above. Table 1 Panel A shows variable definitions.

\subsection{Data Sample and Sources}

We acquire bank data from quarterly Call Reports, which contain financial information on all U.S. commercial banks, over the period 1986:Q1 to 2009:Q4. ${ }^{14}$ We adjust the data to be in real 2009:Q4 terms using the GDP price deflator. We omit observations that do not refer to commercial banks, observations with missing or incomplete financial data on basic accounting variables such as total assets and equity, as well as those with no outstanding loans or deposits. Finally, following Berger and Bouwman (2013) and others, for all observations with total equity less than $1 \%$ of total assets, we replace equity with $1 \%$ of total assets to minimize distortions in ratios that contain equity. ${ }^{15}$ Variables are aggregated for each bank over financial crises and normal time periods. These leaves us with a final sample of 48,532 bank-time period observations for 15,993 commercial banks over the sample period. ${ }^{16}$

\subsection{Control Variables}

In our main performance regressions, we specify both a basic and a broad set of control variables. The basic set includes COST EFF MOMENTUM and PROFIT EFF MOMENTUM, the proportions of quarters in

\footnotetext{
${ }^{14}$ We focus on U.S. commercial banks, rather than BHCs, given that banks within holding companies have their own board of directors and managers, and thus many of the managerial decisions are made at the bank level. In addition, BHCs engage in many other activities that are more difficult to standardize than our simple banking outputs. However, we do control for whether banks are members of BHCs in all our models to capture any differences that may be driven by this membership.

${ }^{15}$ For example, if a bank's capital to GTA ratio is less than $1 \%$, we calculate ROE as net income divided by $1 \%$ of assets. Otherwise, for observations for which equity is between $0 \%$ and $1 \%$ of assets, dividing by equity would result in extraordinarily high values. When equity is negative, the conventionally-defined ROE would have a reversed sign and would not make economic sense. We do not drop these low or negative capital observations because they are likely the most informative of banks' ability to survive and thrive during financial crises.

${ }^{16}$ In an unreported robustness test, we exclude bank-time period observations $(5,466)$ that are affected by mergers as per the Federal Reserve Bank of Chicago mergers dataset. All our results remain consistent and similar to our main findings using this treatment of the data. We keep these observations in for our main analysis as M\&As are key ways in which banks may improve their performance.
} 
which the cost and profit function residual ranks, respectively, improved over the normal times period. It is expected that banks that improved their efficiencies more over a normal times period would have more momentum to perform better over the subsequent crisis period than banks that decreased efficiency. The basic controls also include CRISIS FIXED EFFECTS, the set of individual crises dummies, which act as time fixed effects.

In the broad set of controls, we also include proxies for risk and opacity, size and safety net protection, ownership, organizational structure and strategy, competition, and location, described below. In all cases, the control variables are measured during each pre-crisis normal-times period before the performance variables, which are measured during the subsequent crises.

\subsubsection{Risk and Opacity Indicators}

Banks with riskier and more opaque portfolios in the pre-crisis normal times may be more likely to fail, have higher risk, and less profitability during subsequent financial crises (e.g., $\mathrm{Ng}$ and Rusticus, 2011). Proxies for risk and opacity are as follows. CAPITAL RATIO: Bank capitalization is defined as the bank's equity divided by GTA. It measures the extent to which a bank can absorb potential losses and is generally thought to be associated with improved monitoring and reduced moral hazard incentives to take risk. This variable is found to reduce probability of failure in almost all bank failure studies (e.g., Cole and White, 2012) and to improve performance during financial crises (e.g., Berger and Bouwman, 2013). TOTAL LOANS / GTA: The ratio of total loans to GTA. Banks with higher loan ratios tend to have greater credit risk. COMMERCIAL RE RATIO: Commercial real estate loans divided by GTA. Research finds that commercial real estate loans is an important determinant of bank failures during the recent financial crisis (e.g., Cole and White, 2012; Berger, Imbierowicz, and Rauch, 2016). BROKERED DEPOSITS RATIO: Brokered deposits divided by GTA. Some banks obtain large deposits from deposit brokers. Such deposits however are expensive, and the funds are usually invested in high-risk activities to cover the high costs. While some researchers suggest that brokered deposits cannot directly explain bank failure (e.g., Rossi, 2010), others suggest otherwise (e.g., Federal Deposit Insurance Corporation, 2011; Cole and White, 2012). 
UNUSED COMMITMENTS RATIO: Unused commitments divided by GTA. As noted in Cornett, McNutt, Strahan, and Tehranian (2011), unused commitments expose banks to liquidity risk, and also experience an increase in demand during crises. CASH HOLDINGS RATIO: Cash holdings divided by GTA. High cash holding can reduce liquidity risk for banks and could help them survive, but they can also be associated with more agency problems (e.g., Jensen 1986). LLA / GTA: Loan loss allowance divided by GTA. The loan loss allowance measures expected future loan losses, and indicates greater credit risk. ${ }^{17} \mathrm{LOAN}$ CONCENTRATION: A bank's loan portfolio concentration is measured as a Herfindahl-Hirschman Index (HHI) of the following six loan categories: commercial real estate, residential real estate, commercial and industrial, consumer, agriculture, and other loans. The larger is the loan HHI is, the more concentrated and potentially riskier is the loan portfolio.

\subsubsection{Size and Regulatory Indicators}

We control for size and safety net protection using several indicators. $L N(G T A)$ : The natural log of GTA. Bank size is expected to have favorable effects on future performance because larger banks are better diversified, have higher survival odds, and scale economies. The largest banks may also have better safety net protection, which we deal with in a robustness check below. We control for the primary federal supervisor, which may affect bank performance during financial crises because of differences in quality of

oversight and leniency: SUPERVISOR_OCC (for national banks), SUPERVISOR_FDIC (for state nonmember banks), and SUPERVISOR_FRS (for state banks that are members of the Federal Reserve System). We exclude the latter from the regressions to avoid perfect collinearity.

\subsubsection{Bank Ownership Indicators}

We use two indicators of bank ownership. BHC MEMBER: Dummy equal to one if the bank was part of a bank holding company (BHC) at any time in the period preceding the crisis. BHC membership is expected

\footnotetext{
${ }^{17}$ We obtain qualitatively similar results when using the ratio of nonperforming loans to GTA instead of LLA/GTA as a proxy for bank asset quality.
} 
to help a bank survive, reduce its risk, improve its profitability during a crisis because the holding company may act as a source of strength to all the banks it owns (Houston, James, and Marcus, 1997). PUBLICLY LISTED: Dummy equal to 1 if a bank is listed or is part of a BHC that is listed. Banks that are publicly listed have increased monitoring from shareholders and an additional source for raising capital, which may positively affect performance. Alternatively, it may increase failure probability and risk because of heightened incentives to take advantage of debt holders and the government safety net relative to private owners, which are often family members (e.g., Armour and Gordon, 2014; Cheng, Hong, and Scheinkman, 2015). FOREIGN OWNERSHIP: Foreign ownership dummy equal to 1 if a bank has $50 \%$ or more foreign ownership.

\subsubsection{Organizational Structure Indicators}

Centralized organizations are complex and tend to rely on hard information, while decentralized organizations are less complex and rely more on soft information (Stein, 2002), so organizational complexity may affect performance. We create two variables that capture this complexity: BRANCHES / GTA: (ratio of total bank branches over GTA) x 1000, and LN (NUMBER STATES): Natural log of the number of states in which the bank has branches. Banks with more branches per dollar of assets and those that operate in more states tend to have more complex organizational structures.

\subsubsection{Competition Indicators}

Some research suggests that increased competition reduces franchise value and increases risk and the likelihood of failure (e.g., Keeley, 1990). Others argue that competition reduces risk and the likelihood of failure (e.g., Boyd and De Nicolo, 2005). Still others suggest the relation may be nonmonotonic (e.g., Martinez-Miera and Repullo, 2010). The empirical research finds some merit in all of these positions (e.g., Beck, Demirguc-Kunt, and Levine, 2006; Beck, 2008; Beck, De Jonghe, and Schepens, 2013; Berger, Imbierowicz, and Rauch, 2016). We control for the degree of bank local competition, proxied by $H H I$ DEPOSITS, measured using the Herfindahl-Hirschman Index (HHI) of market concentration based on the 
bank's weighted market share of deposits in the markets in which it operates. Markets are Metropolitan Statistical Areas (MSAs), New England County Metroplitan Areas (NECMAs), or rural counties. ${ }^{18}$ The larger is HHI, the greater is a bank's market power. Finally, we control for PERCENT METROPOLITANpercentage of bank deposits in metropolitan markets (MSAs and CBSAs). Banks with a higher metropolitan presence may experience more competition.

\subsubsection{Local Economic Conditions Indicators}

We use two indicators of local economic conditions. CHANGE COINCIDENT INDEX: Weighted average of the changes in the Philadelphia Federal Reserve's state coincident indices based on deposit shares. The coincident index combines four state-level indicators to summarize economic conditions. ${ }^{19}$ Banks in states with better economic conditions may be less likely to fail, less risky, and more profitable (e.g., Bayazitova and Shivdasani, 2012). HOUSE PRICE INFLATION: House price index (HPI) growth is the weighted average growth in a state-level HPI from the Federal Housing Finance Agency (FHFA) based on deposit shares. This may have important effects on bank performance since real estate is often used as collateral.

\section{Empirical Analysis}

\subsection{Summary Statistics}

Table 1 Panel B contains summary statistics for all financial crises, and separately for banking and market crises. The dependent performance variables are measured during the crises and the independent efficiency and control variables are measured during the prior normal-times periods. The average bank has a failure (FAILED1) likelihood of $1.7 \%$ when considering actual FDIC bank failures and bank technical default (capitalization ratio of less than 2\%), and a failure (FAILED2) likelihood of $0.8 \%$ when considering actual

\footnotetext{
${ }^{18} \mathrm{HHI}$ is the sum of the squares of the market shares (deposits) of each individual bank. We use the bank deposit data from the FDIC Summary of Deposits for the period 2005 to 2009 combined with data from Christa Bouwman for the period 1986 to 2004.

${ }_{19}$ The four indicators are: nonfarm payroll employment, average hours worked in manufacturing, the unemployment rate, and wage and salary disbursements deflated by the Consumer Price Index. ${ }^{20}$ This last regulatory dummy is omitted from the regressions to avoid perfect collinearity.
} 
FDIC failures alone. The risk variables are LN(ZSCORE), with a mean of 3.200 (mean of ZSCORE is 49.243), and standard deviation of ROA, $\sigma R O A$, with a mean of 0.008. Bank ZSCORE, which measures risk inversely, is considered to be the more complete measure of risk, since it takes into account capital and mean earnings, as well as the standard deviation of earnings. Profitability is measured by return on assets $(R O A)$ with a mean of 0.005 ; and return on equity $(R O E)$ with a mean of 0.059 .

Our key independent variables measured during the pre-crisis normal times periods are COSTEFF, with a mean of 0.500 , and PROFITEFF, with a mean of 0.498 . The efficiency means are around 0.50 by construction of the ranks.

Turning to the controls, COST EFF MOMENTUM and PROFIT EFF MOMENTUM have means of 0.596 and 0.591 , respectively. These means exceed the means of the efficiency rank distributions of 0.50 because the banks with the lowest efficiency scores tend to fail or be acquired and drop out of the sample. Regarding risk and opacity characteristics, the average bank has capitalization ratio (CAPITAL RATIO) of 0.101, TOTAL LOANS / GTA of 0.557, COMMERCIAL RE RATIO of 0.146, BROKERED DEPOSITS RATIO of 0.007, UNUSED COMMITMENTS RATIO of 0.075, CASH HOLDINGS RATIO of 0.070, LLA / GTA ratio of 0.009 , and a LOAN CONCENTRATION of 0.316 . Regarding size and safety net protection characteristics, the average bank has a size $L N(G T A)$ of 11.454 (mean of GTA is $\$ 621.583$ million) and $29.7 \%, 60.9 \%$, and $9.4 \%$ have OCC, FDIC, and FRS as their primary federal regulator, respectively. ${ }^{20}$ As regards ownership, $72.1 \%$ of the banks are in BHCs (BHCs), $11.5 \%$ of the banks are publicly listed, and 9\% of the banks are foreign-owned. For ownership structure, the average banks has BRANCHES / GTA of 0.030 and $L N(N U M B E R$ STATES) of 0.012. In terms of competition, the average bank has a $H H I$ DEPOSITS of 0.086 and PERCENT METROPOLITAN of 0.466. Finally, local economic indicators show that the average bank is exposed in the markets in which it operates to a CHANGE COINCIDENT INDEX of 0.206 and HOUSE PRICE INFLATION of 0.426 .

\footnotetext{
20 This last regulatory dummy is omitted from the regressions to avoid perfect collinearity.
} 
When looking at key variables over banking versus market financial crises, statistics are mostly consistent, except that we observe more failures and higher risk during banking crises. With regard to controls, the average bank has a higher COMMERCIAL RE RATIO, higher BROKERED DEPOSITS RATIO, higher LLA / GTA, negative values for the CHANGE COINCIDENT INDEX, and lower increases in HOUSE PRICE INFLATION prior to banking crises, suggesting more increases in risk in the normal times leading to banking crises.

\subsection{Regression Analysis Based on Grouping Financial Crises Together}

In this section, we discuss the main empirical results based on grouping financial crises together.

\subsubsection{How Does Pre-Crisis Efficiency Affect Banks' Likelihood of Failure during Financial Crises?}

Table 2 Panel A present the bank failure regression coefficients with minimal controls. Columns (1), (3), and (5) use the FAILED1 measure, while columns (2), (4), and (6) show results using FAILED2. We use logit models and include only cost efficiency in Columns (1) and (2), only profit efficiency in Columns (3) and (4), and both efficiency measures in Columns (5) and (6). Panel B has the same format, but uses the full set of control variables.

We consistently find that pre-crisis cost efficiency statistically significantly helps banks reduce their probability of failure during financial crises. Turning to economic significance, in the most complete specifications in Panel B Columns (5) and (6), we find that moving cost efficiency during normal times from 0 to 1, i.e., from the most inefficient to the most efficient, decreases the probability of bank failure during financial crises by $64 \%$ (from 0.028 to 0.010 ) in Column (5) for FAILED1 and $95 \%$ (from 0.043 to 0.002) in Column (6) for FAILED2. These results support the good management channel over the skimping channel, consistent with the empirical dominance of Hypothesis 1a over $\mathbf{1 b}$

The results also suggest that profit efficiency generally has no statistically or economically significant effect on the likelihood of failure. When controlling for cost efficiency, the coefficient is only marginally statistically significant in one case and much smaller than the cost efficiency effect. Since profit 
efficiency is inclusive of both costs and revenues, and cost efficiency has a strong negative effect on the probability of failure, these results provide at least modest evidence of the risk-taking channel - that revenues decline during subsequent financial crises from high revenues from additional risk-taking during pre-crisis normal times. These results suggest that neither Hypothesis $2 \mathbf{a}$ nor $\mathbf{2 b}$ empirically dominate because the cost and revenue effects cancel each other out.

Turning to the controls in Table 2 Panel B, the coefficients generally have the predicted signs. Banks with cost and profit efficiency momentum, larger size, higher capitalization, lower ratio of total loans, members of BHCs, lower ratios of commercial real estate loans, fewer brokered deposits, less unused commitments, reduced loan loss allowance ratios, publicly traded, with positive changes in coincident indices and house price inflation, and lower loan concentrations are less likely to fail during the financial crises. The other controls do not have clear sign predictions.

\subsubsection{How Does Pre-Crisis Efficiency Affect Bank Risk during Financial Crises?}

Table 3 presents the results for our proxies of bank risk during financial crises, LN(ZSCORE) and $L N(\sigma R O A)$, following the same format as Table 2. Cost efficiency decreases risk during crises in all cases, and is statistically significant in all but one case. The findings are economically significant for the more complete $L N(Z S C O R E)$ measure, but not for $\sigma R O A$. In the most complete specification in Panel B Columns (5) and (6), we find that moving cost efficiency during normal times from 0 to 1 increases $L N(Z S C O R E)$ during financial crises by $8.5 \%$ (from 3.07 to 3.33 ) in Column (5), which is economically significant, and produces an average reduction in $\sigma R O A$ by $33 \%$ (from 0.009 to 0.006 ) in Column (6). The risk results again support the good management channel over the skimping channel, and the empirical dominance of Hypothesis 1a over $1 \mathrm{~b}$.

Profit efficiency does not have statistically significant effects on risk in the full specification in Panel $\mathrm{B}$, and has a deleterious effect on risk in Panel A, as reflected by statistically lower $L N(Z S C O R E)$. Since cost efficiency during normal times is found above to reduce risk during financial crises, the profit 
efficiency findings suggest that high revenues during normal times are associated with increased risk during the subsequent financial crises. Thus, the data suggest that profit efficiency during normal times may partially reflect engagement in high expected return-high risk activities that have negative consequences during subsequent crises, consistent with the risk-taking channel and the empirical dominance of Hypothesis $2 \mathbf{b}$ over $2 \mathbf{a}$.

Turning to the controls, most of the coefficients are in line with expectations. Banks with more efficiency momentum, larger sizes, lower loan ratios, BHC members, lower ratios of commercial real estate loans, lower ratios of brokered deposits, positive changes in economic conditions, and lower loan concentration tend to reduce have lower risk during subsequent financial crises.

\subsubsection{How Does Pre-Crisis Efficiency Affect Banks' Profitability during Financial Crises?}

Table 4 presents the results for the two measures of bank profitability, ROA and ROE, again following the same format. Cost efficiency consistently increases profitability during subsequent crises, while profit efficiency has little effect. The cost efficiency coefficients are all statistically significant and are economically significant for $R O E$ as well. In Panel B Columns (5) and (6), we find that moving cost efficiency during normal times from 0 to 1 increases $R O A$ during financial crises by $75 \%$ (from 0.004 to 0.007) in Column (5), and increases ROE during financial crises by $51 \%$ (from 0.047 to 0.071 ) in Column (6). Again, the results support the good management channel over the skimping channel and are consistent with empirical dominance of Hypothesis 1a over $\mathbf{1 b}$.

The profit efficiency results, by contrast, show no increase in profitability during subsequent crises. The coefficients are small, and the only ones that are significant are negative. Again, since profit efficiency is inclusive of cost efficiency, the marginal effects of higher revenues during normal times presage decreases in profitability during the following financial crises, more consistent with the risk-taking

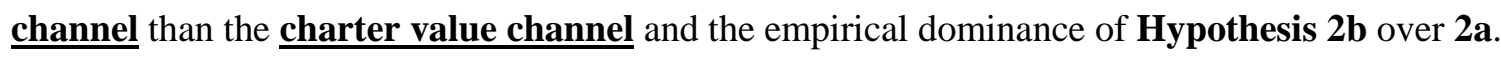

Turning to the controls, we find that banks with more efficiency momentum, greater size, BHC 
membership, higher ratio of unused commitments, being publicly traded, having positive changes in the local market conditions where they operate as proxied by the coincident index and house price inflation, and a lower loan concentration are more likely to have strong profit performance during subsequent financial crises.

\section{Robustness Checks}

This section presents our robustness checks. In all cases, we use only the full specifications with both cost and profit efficiency and the broad set of controls, although most of the controls are not shown for brevity.

\subsection{Effects for Banking Crises and Market Crises}

We examine whether results differ for the two banking crises versus the three market crises in our sample. Table 5 shows the results. They suggest that all of our effects of cost efficiency on bank performance hold consistently during banking crises, and hold in only some cases during market crises. Our non-results for profit efficiency occur in almost all cases for both types of crises.

\subsection{Excluding Too-Big-to-Fail (TBTF) Banks}

Another issue is that our results may be driven by the very large banks considered too-big-to-fail (TBTF), and more likely to be bailed out in the event of problems. To mitigate this concern, we rerun our main analyses while excluding these banks. There is no formal definition of TBTF, so we use two alternative definitions. First, in every period, we deem all banks with GTA of at least $\$ 50$ billion to be TBTF, consistent with the Dodd-Frank Act definition of systemically important financial institutions (SIFIs). Second, we classify the 19 largest institutions in each period as TBTF, consistent with the Federal Reserve's determination in 2009 that the 19 largest banks were subject to stress tests. Table 6 shows results alternatively excluding these two groups. We find similar results to our main findings, suggesting that our conclusions are not driven by the TBTF banks. ${ }^{21}$

21 There are not enough observations to analyze the TBTF banks by themselves. 


\subsection{Controlling for Cost-to-Income}

To ensure robustness, we also replicate our results when controlling for a simpler measure of efficiency used in the literature - COST-TO-INCOME, or total bank costs relative to total revenues (e.g., Beck, Demirgüç-Kunt, and Merrouche, 2013). We also separately control for COST-TO-INCOME RANK, computed analogously to our efficiency ranks. These results are reported in Table 7 and show that these additional variables are either marginally statistically significant or insignificant, while our main results remain qualitatively unaffected.

\subsection{Alternative Pre-Crisis Period}

Our main results are based on regressions that use efficiencies and control variables computed over all time periods between crises. Using the most data reduces sensitivity to the effects of outliers. As robustness checks, we rerun our regressions while measuring efficiency and control variables averaged over the four quarters before a crisis. These results are reported in Table 8 and show results similar to the main results. ${ }^{22}$

\subsection{Effects by Bank Size}

Prior banking research has inconclusive results on the relations between bank size and efficiency. Some studies find that large banks achieve more cost and profit efficiencies than small banks (Tecles and Tabak, 2010; Manlagnit, 2011), while others find that small banks achieve more profit efficiency than large banks (e.g., Mamatzakis, Staikouras and Koutsomanoli-Filippaki, 2008). To account for the fact that effects of efficiency may be different for small banks (GTA $\leq \$ 1$ billion) and large banks (GTA $>1$ billion), we rerun our analyses for these two bank size classes.

Table 9 shows the effects of efficiency on bank performance during financial crises for small banks and large banks. Results suggest that our main findings hold for both small and large banks, but the magnitudes of the coefficients are generally higher for the large banks, although the $t$-statistics and

\footnotetext{
${ }^{22}$ In unreported results, we also tried using up to eight quarters, and results are also consistent.
} 
statistically significance are generally greater for small banks, likely due to the much larger numbers of observations. ${ }^{23}$

\subsection{Non-Monotonicity of the Effects}

In Table 10, we rerun our tests, including quadratic terms of our cost and profit efficiency measures, COSTEFF_SQ and PROFITEFF_SQ, respectively, to account for the possibility of nonlinear relations between bank efficiency pre-crisis and performance during crises. The coefficients on the linear terms for COSTEFF are all statistically significant and of the same sign as in our main specification, while the coefficients on the quadratic terms COSTEFF_SQ have opposing signs and are also statistically significant, consistent with the existence of U- or upside-down U-shaped relations.

We calculate the inflection points of the quadratic functions of cost and profit efficiency for each performance indicator and determine the percent of observations for which the findings run in the same direction as our main results. For the cost efficiency, the inflection points are 0.739 and 0.782 for the failure models, 0.856 and 0.896 for the risk models, and 0.807 and 1.952 for the profitability models. ${ }^{24}$ We also report the percent of observations for which the main relation holds. We find that for all six dependent variables, the effects of cost efficiency go in the same direction as in our main analyses for more than $90 \%$ of the observations. Thus, the data are consistent with our conclusions that higher cost efficiency results in improved bank performance during financial crises. As in our main analysis, profit efficiency during normal times has no consistent effects on bank performance during subsequent financial crises.

\section{Deeper Analysis of the Cost Efficiency Findings}

Our results so far suggest that cost efficiency during normal times helps banks perform better during subsequent financial crises, consistent with the good management channel underlying Hypothesis 1a. We next examine more carefully the extent to which this channel explains the data and whether or not the

\footnotetext{
${ }^{23}$ In unreported results, we redefine small and large banks based on the median of bank GTA and results are qualitatively similar.

${ }^{24}$ Inflection points are calculated as (-coefficient of the linear terms)/(2xcoefficient of the quadratic term).
} 
alternative skimping channel may find any support.

To do so, we first test whether the cost efficiency-performance relations are stronger for well managed versus poorly managed banks using regulatory enforcement actions against bank management data in the pre-crisis period to proxy for management quality following the extant research (e.g., Duchin and Sosyura, 2014; Fiordelisi, Raponi, and Rau, 2015; Delis, Staikouras, and Tsoumas, 2016). Banking regulators issue formal, publicly announced enforcement actions against bank management officials if these individuals are found to engage in unsafe, unsound, or illegal banking practices, ${ }^{25}$ or other significant violations of laws, rules, or regulations. Information on regulatory enforcement actions against management is acquired via manual collection from the federal regulators OCC, FDIC, and FRS. We group banks according to whether they did not or did receive enforcement actions against management in the pre-crisis period, Enforcement Actions against Management $=0$ or Enforcement Actions against Management $>0$, and estimate the model for both subsamples. To the extent that the good management channel is in effect, it is expected that cost efficiency would have its most favorable effects for the better-managed banks that have no enforcement actions.

Regression estimates testing this are shown in Table 11, columns (1) through (12), where we show the full specifications for the performance measures for the subsamples of banks without and with enforcement actions. The effects of cost efficiency are statistically significant in all cases for the banks without enforcement actions. In contrast, they are insignificant in all cases and have the opposing signs for failure and profitability for banks with enforcement actions.

Results for the banks without enforcement actions are also economically significant. For these banks, moving cost efficiency during normal times from 0 to 1 decreases the probability of bank failure during financial crises by $64 \%$ (from 0.028 to 0.010 ) in Column (1) for FAILED1 and $96 \%$ (from 0.045 to 0.002) in Column (6) for FAILED2. Similarly, looking at bank risk for banks without enforcement actions,

\footnotetext{
${ }^{25}$ Unsafe or unsound practices are any actions or omissions which are contrary to generally accepted standards of prudent bank operation and, if continued, are likely to lead to abnormal risk or loss to the institution and its stakeholders.
} 
we find that moving cost efficiency during normal times from 0 to 1 increases $L N(Z S C O R E)$ during financial crises by $8.5 \%$ (from 3.07 to 3.33 ) in Column (5), and reduces $\sigma R O A$ by $22 \%$ (from 0.009 to 0.007 ) in Column (6). Finally, we find that moving normal-times cost efficiency from 0 to 1 for banks without actions increases $R O A$ during financial crises by $75 \%$ (from 0.004 to 0.007 ) in Column (9), and increases $R O E$ during financial crises by $51 \%$ (from 0.047 to 0.071 ) in Column (10). The results are strongly consistent with the good management channel - the effects of normal-times cost efficiency on subsequent financial crisis performance are only favorable and statistically and economically significant for the banks with no enforcement actions against management.

Table 11 columns (13) - (14) provide direct tests of the skimping channel by examining whether high cost efficiency during normal times is associated with more loan performance problems during subsequent financial crises. To measure loan performance problems, we use the ratio of nonperforming loans (past due at least 90 days or in nonaccrual status) to total loans, $N P L$, and the the ratio of the loan and lease loss allowance to total loans, $L L A$. The evidence does not support the skimping channel - cost efficiency is instead associated with fewer loan performance problems. ${ }^{26}$

\section{Conclusions}

We test the effects of bank efficiency in normal times on bank performance during subsequent financial crises. We find that cost efficiency during normal times helps banks reduce failure probabilities, decrease risk, and enhance profitability during subsequent financial crises, while profit efficiency has limited benefits. This suggests that cost efficiency may better proxy management quality, while profit efficiency may partially reflect temporary high returns during normal times from risky investments that are reversed during subsequent financial crises. Results are robust to various checks. A deeper analysis confirms that high cost efficiency is associated with good management.

\footnotetext{
${ }^{26}$ In unreported results, we rerun tests for small banks (GTA $\leq \$ 1$ billion) and large banks (GTA $>\$ 1$ billion) and find that both small and large banks with higher cost efficiency in the pre-crisis period experience fewer loan performance problems during financial crises.
} 
These results also yield important potential policy and research implications. Our findings suggest that bank stakeholders - policymakers, regulators, supervisors, owners, creditors, and managers - may consider closer monitoring of banks with low cost efficiency early so as to reduce the occurrence of problems during future financial crises. In addition, bank managers may consider policies and procedures that promote cost efficiency, which may drive better bank performance during subsequent crises. With respect to research implications, our findings suggest that researchers consider relying more on cost efficiency as an indicator of bank quality than profit efficiency. The results also suggest that future research focus more on intertemporal issues in banking - what happens during normal times has important implications for subsequent financial crises. 


\section{References}

Acharya, V.V., Cooley, T.F., Richardson, M.P., and Walter, I., 2011. Market failures and regulatory failures: Lessons from past and present financial crises, ADBI Working Paper No. 264.

Acharya, V., Philippon, T., Richardson, M., Roubini, N. 2009. The Financial Crisis of 2007-2009: Causes and Remedies. Financial Markets, Institutions and Instruments 18, 89-137.

Acharya, V., Richardson, M. 2009. Causes of the Financial Crisis. Critical Review 21, 195-210.

Admati, A.R., DeMarzo, P.M., Hellwig M.F., Pfleiderer, P.C., 2011. Fallacies, irrelevant facts, and myths in the discussion of capital regulation: Why bank equity is not expensive. Unpublished working paper. Stanford University and Max Planck Institute, Stanford, CA, and Bonn, Germany.

Armour, J., Gordon, J., 2014. Systemic harms and shareholder value. Journal of Legal Analysis, 6, 35-85.

Ashcraft, A., 2005. Are banks really special? New evidence from the FDIC-Induced failure of healthy banks. American Economic Review 95, 1712-30.

Atkinson, T., Luttrell, D., Rosenblum, H. 2013. How Bad Was It? The Costs and Consequences of the 2007-09 Financial Crisis. Federal Reserve Bank of Dallas Staff Papers.

Aubuchon, C.P. and Wheelock, D.C., 2010. The geographic distribution and characteristics of US bank failures, 2007-2010: do bank failures still reflect local economic conditions? Federal Reserve Bank of St. Louis Review 92, 395-415.

Barth, J. R., P. Bartholomew, and M. Bradley. 1990. Determinants of thrift institution resolution costs. Journal of Finance 45, 731-54.

Bayazitova, D., Shivdasani, A., 2012. Assessing TARP. Review of Financial Studies 25, 377-407.

Beck, T., Demirguc-Kunt, A., Levine, R., 2006. Bank concentration, competition, and crises: first results. Journal of Banking and Finance 30, 1581-1603.

Beck, T., 2008. Bank competition and financial stability: Friends or foes? Unpublished working paper. Tilburg University, Tilburg, the Netherlands.

Beck, T., De Jonghe, O., Schepens, G., 2013, Bank competition and stability: Cross-country heterogeneity, Journal of Financial Intermediation, 22: 218-244.

Beck, T., Demirgüç-Kunt, A., Merrouche, O., 2013. Islamic vs. conventional banking: Business model, efficiency and stability. Journal of Banking \& Finance, 37, 433-447.

Berger, A.N., 1993. "Distribution-Free" Estimates of Efficiency in the U.S. Banking Industry and Tests of the Standard Distributional Assumptions. Journal of Productivity Analysis 4, 261-292.

Berger, A.N., Bouwman, C.H.S., 2009. Bank liquidity creation. Review of Financial Studies 22, 37793837.

Berger, A.N., Bouwman, C.H.S., 2013. How Does Capital Affect Bank Performance during Financial Crises? Journal of Financial Economics 109, 146-176.

Berger, A.N., DeYoung, R., 1997. Problem loans and cost efficiency in commercial banks. Journal of Banking and Finance, 21, 849-870.

Berger, A. N., Hancock, D., Humphrey, D.B., 1993, Bank efficiency derived from the profit function, Journal of Banking and Finance, 17, 317-47.

Berger, A. N., Hanweck, G.A., Humphrey, D.B., 1987, Competitive viability in banking: Scale, scope, and product mix economies, Journal of Monetary Economics 20, 501-520.

Berger, A.N., Imbierowicz, B., Rauch, C., 2016. The roles of corporate governance in bank failures during the recent financial crisis. Journal of Money, Credit, and Banking 48, 729-770.

Berger, A.N., Mester, L.J., 1997. Inside the black box: What explain differences in the efficiencies of financial institutions? Journal of Banking and Finance, 21, 895-947.

Berger, A.N., Udell, G.F., 2004. The institutional memory hypothesis and the procyclicality of bank lending behavior. Journal of Financial Intermediation, 13, 458-495.

Bernanke, B., 2006. Bank Regulation and Supervision: Balancing Benefits and Costs, Speech, Before the Annual Convention of the American Bankers Association, Phoenix, Arizona, and the Annual Convention of America's Community Bankers, San Diego, California, http://www.federalreserve.gov/newsevents/speech/bernanke20061016a.htm. 
Boyd, J., De Nicolo, G., 2005. The theory of bank risk taking and competition revisited. Journal of Finance 60, 1329-1343.

Boyd, J., Prescott, E.E., 1986. Financial Intermediary-Coalitions. Journal of Economic Theory 38, 211-32.

Bryant, J. 1980. A Model of Reserves, Bank Runs, and Deposit Insurance. Journal of Banking and Finance $4,335-44$.

Calomiris, C.W. and Carlson, M., 2017. Corporate governance and risk management at unprotected banks: national banks in the 1890s. Journal of Financial Economics 125, 434-453.

Calomiris, C. W. and J. R. Mason. 1997. Contagion and Bank Failures during the Great Depression: The June 1932 Chicago Banking Panic. American Economic Review 87, 863-83.

Calomiris, C. W. and J. R. Mason., 2003. Fundamentals, Panics and Bank Distress during the Depression. American Economic Review 93, 1615-47.

Carletti, E., Hartmann, P., 2003. Competition and financial stability: What's special about banking? In: Mizen P. (eds.), Monetary history, exchange rates and financial markets: Essays in honor of Charles Goodhart. Vol.2. Edward Elgar, Cheltenham, UK.

Cebenoyan, A.S., Cooperman, E.S., Register, C.A., Hudgins, S.C., 1993. The relative efficiency of stock vs. mutual S\&Ls: A stochastic frontier approach. Journal of Financial Services Research 7, 151-170.

Cheng, I.H., Hong, H., Scheinkman, J.A., 2015. Yesterday's heroes: compensation and risk at financial firms. The Journal of Finance 70, 839-879.

Cole, R. A. and Gunther, J.W., 1995. Separating the timing and likelihood of bank failure. Journal of Banking and Finance 19, 1073-1089.

Cole, R. A. and Gunther, J.W., 1998. Predicting bank failures: A comparison of on- and off-site monitoring systems. Journal of Financial Services Research 13, 103-117.

Cole, R. A. and White, L. J., 2012, Déjà vu all over again: the causes of US commercial bank failures this time around. Journal of Financial Services Research 42, 5-29.

Cornett, M.M., McNutt, J.J., Strahan, P.E. Tehranian, H., 2011. Liquidity risk management and credit supply in the financial crisis. Journal of Financial Economics, 101, 297-312.

Diamond, D.W. 1984. Financial Intermediation and Delegated Monitoring. Review of Economic Studies $51,393-414$.

Diamond, D.W., Dybvig, P.H., 1983. Bank Runs, Deposit Insurance, and Liquidity. Journal of Political Economy 91,401-19.

Delis, M.D., Staikouras, P.K., Tsoumas, C., 2016. Formal enforcement actions and bank behavior. Management Science 63, 959 - 987.

Demsetz, R.S., Saidenberg M. R., Strahan, P. E., 1996. Banks with something to lose: the disciplinary role of franchise value. Federal Reserve Bank of New York, Economic Policy Review 2, 1-14.

DeYoung, R., Torna, G., 2013. Nontraditional banking activities and bank failures during the financial crisis. Journal of Financial Intermediation 22, 397-421.

Diamond, D.W., Rajan, R. 2009. The Credit Crisis: Conjectures about Causes and Remedies. Working Paper.

Duchin R., Sosyura, D., 2014. Safer ratios, riskier portfolios: Banks' response to government aid. Journal of Financial Economics 113, 1-28.

Elsinger, H., Lehar, A., Summer, M., 2006. Risk assessment for banking systems. Management Science 52, 1301-1314.

Espahbodi, P., 1991. Identification of problem banks and binary choice Columns, Journal of Banking and Finance 15, 53-71.

Fahlenbrach, R., Stulz, R.M., 2011. Bank CEO incentives and the credit crisis. Journal of Financial Economics 99(1), 11-26.

Federal Deposit Insurance Corporation, 2011. Study on core deposits and brokered deposits submitted to Congress pursuant to the Dodd-Frank Wall Street Reform and Consumer Protection Act.

Federal Deposit Insurance Corporation, 2013, Managing the Crisis: The FDIC and RTC Experience, Chapter 8, The FDIC's Role as Receiver.

Fiordelisi, F., Marques-Ibanez, D., Molyneux, P., 2011. Efficiency and risk-taking in European banking. 
Journal of Banking and Finance, 35, 1315-1326.

Fiordelisi, F., Raponi, J., and Rau P.R., 2015. Corporate culture and enforcement actions in banking, Working Paper.

Gallant, A. R., 1981. On the bias in flexible functional forms and an essentially unbiased form: The Fourier flexible form. Journal of Econometrics, 15, 211-245.

Gallant, A. R., 1982. Unbiased determination of production technologies. Journal of Econometrics, 20, 285323.

Garcia, G. 2015. The U.S. Financial Crisis and the Great Recession: Counting the Costs. World Scientific - NOW Publishers Series.

Giannetti, M. and Ongena, S., 2009. Financial integration and firm performance: Evidence from foreign bank entry in emerging markets. Review of Finance 13, 181-223.

Government Accountability Office 2013. Financial Crisis Losses and Potential Impacts of the Dodd-Frank Act, Report to Congressional Requesters, January 16, www.gao.gov/products/GAO-13-180.

Greenspan, A., 2001. The financial safety net, Speech at the 37th Annual Conference on Bank Structure and Competition of the Federal Reserve Bank of Chicago.

Helwege, J., 1996, Determinants of Savings and Loan failures: Estimates of a time-varying proportional hazard function, Journal of Financial Services Research 10, 373-392.

Hellmann, T.F., Murdock, K.C., Stiglitz, J.E., 2000. Liberalization, moral hazard in banking, and prudential regulation: Are capital requirements enough? American Economic Review 90, 147-165.

Hermalin, B.E., Wallace, N.E., 1994. The determinants of loans. Rand Journal of Economics 25, 361-381.

Hong, H., Huang, J.-Z., and Wu, D. 2014. The information content of Basel III liquidity risk measures, Journal of Financial Stability 15, 91-111.

Houston, J. F., James, C., Marcus, D., 1997. Capital market frictions and the role of internal capital markets in banking. Journal of Financial Economics 46, 135-164.

Hughes, J. P., Mester, L.J., 2013, Who said large banks don't experience scale economies? Evidence from a risk-return-driven cost function, Journal of Financial Intermediation, 22, 559-585.

Hughes, J.P., Mester, L.M. 2015. Measuring the performance of banks: theory, practice, evidence, and some policy implications, in Berger, A.N., Molyneux, P., and Wilson, J.O.S., eds, Oxford Handbook of Banking, Second Edition, Oxford University Press, Oxford, 247-270.

James, C., 1987. Some evidence on the uniqueness of bank loans. Journal of Financial Economics 19, 217235.

James, C., 1991. The losses realized in bank failures. Journal of Finance 46, 1223-42.

Jensen, M. C., 1986. Agency costs of free cash flow, corporate finance, and takeovers. American Economic Review 76, 323-329.

Jimenez, G., Lopez, J., Saurina, J., 2013. How does competition impact bank risk taking? Working Paper. Banco de Espana.

Kang, A., Lowery, R., and Wardlaw, M., 2014. The costs of closing failed banks: A structural estimation of regulatory incentives. Review of Financial Studies, 28, 1060-1102.

Keeley, M. C., 1990. Deposit insurance, risk, and market power in banking. American Economic Review 80, 1183-1200.

Knaup, M., Wagner, W., 2012. A market-based measure of credit portfolio quality and banks' performance during the subprime crisis. Management Science, 58, 1423-1437.

Kupiec, P.H. and Ramirez, C.D., 2013. Bank failures and the cost of systemic risk: Evidence from 1900 to 1930. Journal of Financial Intermediation 22, 285-307.

Kwan, S., Eisenbeis, R.A., 1997. Bank risk, capitalization, and operating efficiency. Journal of financial services research $12,117-131$.

Laeven, L., Valencia, F., 2012. The use of blanket guarantees in banking crises. Journal of International Money and Finance 31, 1220-1248.

Lane, W. R., Looney, S.W., Wansley, J.W., 1986. An application of the Cox Proportional Hazards models to bank failure. Journal of Banking and Finance 10, 511- 531.

Lang, L., and R. Stulz., 1992. Contagion and Competitive Intra-industry Effects of Bankruptcy 
Announcements. Journal of Financial Economics 32, 45-60.

Lozano-Vivas, A., 1997. Profit efficiency for Spanish savings banks, European Journal of Operational Research, 98, 381-94.

Mamatzakis, E., C. Staikouras and A. Koutsomanoli-Filippaki, 2008. Bank efficiency in new European union member states: Is there convergence? International Review of Financial Analysis, 17, 1156-1172.

Manlagnit, M., 2011. The economic effects of foreign bank presence: Evidence from the Philippines. Journal of International Money and Finance, 30, 1180-1194.

Marcus, A. J., 1984. Deregulation and bank financial policy. Journal of Banking and Finance 8, 557-565.

Martinez-Miera, D., Repullo, R., 2010. Does competition reduce the risk of bank failure? Review of Financial Studies 23, 3638-3664.

Maudos, J., Pastor, J. M., Perez, F., Quesada, J., 2002. Cost and profit efficiency in European banks. Journal of International Financial Markets, Institutions and Money 12, 33-58.

McAllister, P.H., McManus, D., 1993. Resolving the scale efficiency puzzle in banking. Journal of Banking and Finance 17, 389-405.

Mitchell, K., Onvural, N.M., 1996. Economies of scale and scope at large commercial banks: Evidence from the Fourier flexible functional form. Journal of Money, Credit, and Banking 28, 178-199.Molina, C., A., 2002. Predicting bank failures using a hazard model: The Venezuelan banking crisis, Emerging Markets Review 3, 31-50.

Mullineaux, D.J., 1978. Economies of scale and organizational efficiency in banking: a profit-function approach. Journal of Finance 33, 259-280.

Ng, J., Rusticus, T. O., 2011. Banks' survival during the financial crisis: the role of regulatory reporting quality. Unpublished working paper. Singapore Management University and Northwestern University, Singapore, and Evanston, IL.

Ramakrishnan, R.T.S., Thakor, A.V., 1984. Information Reliability and a Theory of Financial Intermediation. Review of Economics Studies 51, 415-32.

Reinhart, C. M., and Rogoff, K., 2009. This time is different: eight centuries of financial folly. Princeton University Press.

Restrepo-Tobon, D., Kumbhakar, S. C., 2014. Enjoying the quiet life under deregulation? not quite, Journal of Applied Econometrics 29, 333-343.

Rogers, K. E., 1998. Nontraditional activities and the efficiency of U.S. commercial banks, Journal of Banking and Finance 22, 467-82.

Rossi, C. V., 2010. Decomposing the impact of brokered deposits on bank failure: theory and practice. Working paper.

Schaeck, K., 2008. Bank liability structure, FDIC loss, and time to failure: A quantile regression approach, Journal of Financial Services Research 33, 163-179.

Soteriou, A., Zenios, S. A., 1999. Operations, quality, and profitability in the provision of banking services. Management Science 45, 1221-1238.

Stein, J., 2002. Information production and capital allocation: decentralized versus hierarchical firms. Journal of Finance 57, 1891-1922.

Tecles, P. and B. Tabak, 2010. Determinants of bank efficiency: The case of Brazil. European Journal of Operational Research, 207, 1587-1598.

U.S. Department of the Treasury, 2012. The financial crisis response in charts. Available at: https://www.treasury.gov/resource-center/data-chartcenter/Documents/20120413_FinancialCrisisResponse.pdf

Vander Vennet, R., 2002. Cost and profit efficiency of financial conglomerates and universal banks in Europe. Journal of Money, Credit, and Banking 34, 254-282.

Wheelock, D.C. and Wilson, P.W., 1995. Explaining bank failures: Deposit insurance, regulation, and efficiency. Review of Economics and Statistics 77, 689-700.

Wheelock, D.C. and P. Wilson., 2000. Why do banks disappear? The determinants of U.S. bank failures and acquisitions. Review of Economics and Statistics 82,127-38.

Wheelock, D.C. and Wilson, P.W., 2012. Do large banks have lower costs? New estimates of returns to 
scale for US banks. Journal of Money, Credit and Banking, 44, 171-199.

Wheelock, D.C. and Wilson, P.W., 2016. The Evolution of Scale Economies in U.S. Banking. Federal Reserve Bank of St Louis Paper No. FEDLWP2015-021.

Williams, J., 2004. Determining management behavior in European banking. Journal of Banking \& Finance $28,2427-2460$. 


\section{Figure 1: Timeline}

This figure shows the banking crises (BNKCRISIS), market crises (MKTCRISIS), and normal times (NORMAL) that occurred during our sample period from 1986:Q1 until 2009:Q4.

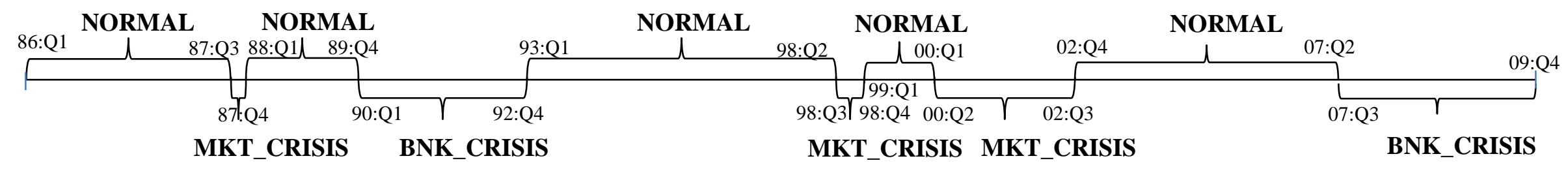

Detailed periods and sequence for our sample period from 1986:Q1 until 2009:Q4 are represented below:

\begin{tabular}{|l|l|}
\hline Period Type & Exact time period \\
\hline NORMAL & $86: Q 1-87: Q 3$ \\
\hline MKT_CRISIS & $87: Q 4$ \\
\hline NORMAL & $88: Q 1-89: Q 4$ \\
\hline BNK_CRISIS & $90: Q 1-92: Q 4$ \\
\hline NORMAL & 93:Q1 - 98:Q2 \\
\hline MKT_CRISIS & 98:Q3 - 98:Q4 \\
\hline NORMAL & 99:Q1 - 00:Q1 \\
\hline MKT_CRISIS & 00:Q2 - 02:Q3 \\
\hline NORMAL & 02:Q4 - 07:Q2 \\
\hline BNK_CRISIS & 07:Q3 - 09:Q4 \\
\hline
\end{tabular}




\section{Table 1: Variable Definitions and Summary Statistics}

Panel A provides definitions for all variables used in our analysis. Panel B reports summary statistics of the variables for our analysis for the period 1986:Q1-2009:Q4. All variables using dollar amounts are expressed in real 2009:Q4 dollars using the implicit GDP price deflator. It contains means, medians, standard deviations and number of observations on all the regression variables used to examine the effect of pre-crisis cost and profit efficiency on banks' ability to survive crises, reduce risk, and increase their performance during such crises. We first present statistics for all financial crises, and then we distinguish between banking crises (the credit crunch of the early 1990s and the recent subprime lending crisis), and market crises (the 1987 stock market crash, the Russian debt crisis plus LTCM bailout in 1998, and the bursting of the dot.com bubble plus September 11).

Panel A - Variable Definitions

\section{Dependent Variables}

\section{FAILURE}

FAILED1 is a dummy equal to one if bank $i$ failed as it was placed under receivership or closed by the FDIC given it was unable to meet its obligations to depositors and other stakeholders and thus it was included in the FDIC failure list, or experienced book-value insolvency or technical default (bank became critically undercapitalized, its equity capitalization fell below $2 \%$ of bank GTA.

FAILED2 is a dummy equal to one if bank $i$ failed as it was placed under receivership or closed by the FDIC given it was unable to meet its obligations to depositors and other stakeholders and thus it was included in the FDIC failure list.

$\underline{\text { RISK }}$

LN(ZSCORE) is a measure of bank financial risk. It is calculated as the log of the sum of a bank's mean ROA (net income over GTA) and mean CAPITAL RATIO (equity capital over GTA) divided by $\sigma R O A$ (the volatility of ROA), where the means of the components are calculated over the crises periods.

$\boldsymbol{\sigma R O A}$ is the volatility of return on assets $R O A$ over the crises periods.

\section{PROFITABILITY}

$\boldsymbol{R O A}$ is the bank return on assets over the crises periods.

$\boldsymbol{R O E}$ is the bank return on equity over the crises periods winsorized at the $1 \%$ level.

\section{OTHER DEPENDENT VARIABLES (Robustness)}

NPL/TL is the bank ratio of nonperforming loans (past due at least 90 days or in nonaccrual status) to total loans.

$\boldsymbol{L L} \boldsymbol{A} / \boldsymbol{G T A}$ is loan loss allowance divided by GTA.

\section{$\underline{\text { Key Independent Variables }}$}

COSTEFF is bank cost efficiency over the pre-crisis periods.

PROFFEFF is bank profit efficiency over the pre-crisis periods.

\section{Basic Characteristics}

COST EFF MOMENTUM is the proportion of quarters in which the cost function residual ranks improved over the normal times period.

PROFIT EFF MOMENTUM is the proportion of quarters in which the profit function residual ranks improved over the normal times period.

\section{Other Bank Characteristics}

\section{A. Risk and Opacity}

CAPITAL RATIO is bank capitalization, defined as the bank's total equity divided by GTA.

TOTAL LOANS / GTA is the ratio of total loans to GTA. 
COMMERCIAL RE RATIO is the commercial real estate loans divided by GTA.

BROKERED DEPOSITS RATIO is brokered deposits divided by GTA.

Other Bank Characteristics (cont.)

\section{A. Risk and Opacity (cont.)}

UNUSED COMMITMENTS RATIO is unused commitments divided by GTA.

CASH HOLDINGS RATIO is cash holdings divided by GTA.

$\boldsymbol{L L A} / \boldsymbol{G T A}$ is loan loss allowance divided by GTA.

LOAN CONCENTRATION is a bank's loan portfolio concentration measured as a Herfindahl-Hirschman Index (HHI) of the following six loan categories: commercial real estate, residential real estate, construction and industrial, consumer, agriculture, and other loans.

\section{B. Size and Safetv Net Protection}

$\boldsymbol{L N}(\boldsymbol{G T A})$ is bank size calculated as the natural log of GTA.

SUPERVISOR_OCC is a dummy equal 1 if the OCC is the primary supervisor of the bank.

SUPERVISOR_FDIC is a dummy equal 1 if the FDIC is the primary supervisor of the bank.

SUPERVISOR_FRS is a dummy equal 1 if the FRS is the primary supervisor of the bank.

\section{Bank Ownership}

$\boldsymbol{B H C} \boldsymbol{M E M B E R}$ is a dummy variable that equals one if a bank was part of a bank holding company (BHC) at any time in the pre-crisis period.

PUBLICLY LISTED is a dummy equal to 1 if a bank is listed or is part of a BHC that is listed on a stock exchange.

FOREIGN OWNERSHIP is a dummy equal to 1 if a bank has $50 \%$ or more foreign ownership.

\section{Organizational Structure}

BRANCHES / GTA is a measure of bank organizational complexity calculated as (ratio of the number of branches the bank has active over GTA) $\times 1000$.

LN (NUMBER STATES) is the log of the number of states in which bank has branches.

\section{$\underline{\text { E. Competition }}$}

HHI DEPOSITS is the bank-level Herfindahl-Hirschman Index (HHI) of deposit concentration for the local markets in which the bank is present.

PERCENT METROPOLITAN is the percentage of bank deposits in metropolitan markets (MSAs and CBSAs) as a fraction of deposits in all markets in which a bank is active.

\section{F. Local Economic Conditions}

CHANGE COINCIDENT INDEX is the weighted average of the changes in the Philadelphia Federal Reserve's state coincident indexes with the share of the deposits of a given bank taken as weights.

HOUSE PRICE INFLATION is the weighted average growth in a state-level house price index with the share of the deposits of a given bank taken as weights.

\section{G. Other Variables (Robustness)}

CRISIS FIXED EFFECTS are a set of individual crisis dummies, which act as time fixed effects.

Enforcement Actions against Management is the number of regulatory enforcement actions against bank management by the corresponding banking regulator (Federal Reserve System (FRS), Federal Deposit Insurance Corporation (FDIC), and Office of the Comptroller of the Currency (OCC)) during the time period.

COST-TO-INCOME is the ratio of bank total costs to total revenue. 
COST-TO-INCOME RANK is the rank of the ratio of bank total costs to total revenue in descending order of efficiency, so that banks with a lower ratio are assigned a higher rank. 
Panel B - Summary Statistics

\begin{tabular}{|c|c|c|c|c|c|c|c|c|c|c|c|c|}
\hline \multirow[b]{2}{*}{ Summary Statistics } & \multicolumn{4}{|c|}{ ALL FINANCIAL CRISES } & \multicolumn{4}{|c|}{ BANKING CRISES } & \multicolumn{4}{|c|}{ MARKET CRISES } \\
\hline & mean & p50 & sd & $\mathbf{N}$ & mean & p50 & sd & $\mathbf{N}$ & mean & p50 & sd & $\mathbf{N}$ \\
\hline \multicolumn{13}{|l|}{ Dependent Crisis Variables } \\
\hline \multicolumn{13}{|l|}{ FAILURE } \\
\hline FAILEDI & 0.017 & 0.000 & 0.128 & 48,532 & 0.030 & 0.000 & 0.170 & 19,066 & 0.008 & 0.000 & 0.091 & 29,466 \\
\hline FAILED2 & 0.008 & 0.000 & 0.089 & 48,532 & 0.019 & 0.000 & 0.138 & 19,066 & 0.001 & 0.000 & 0.023 & 29,466 \\
\hline \multicolumn{13}{|l|}{ RISK } \\
\hline LN(ZSCORE) & 3.200 & 3.332 & 1.368 & 35,150 & 2.768 & 3.021 & 1.387 & 18,990 & 3.708 & 3.699 & 1.153 & 16,160 \\
\hline$\sigma R O A$ & 0.008 & 0.004 & 0.015 & 35,151 & 0.010 & 0.005 & 0.019 & 18,990 & 0.005 & 0.003 & 0.009 & 16,160 \\
\hline \multicolumn{13}{|l|}{ PROFITABILITY } \\
\hline ROA & 0.005 & 0.009 & 0.020 & 48,532 & 0.005 & 0.009 & 0.015 & 19,066 & 0.005 & 0.010 & 0.023 & 29,466 \\
\hline ROE & 0.059 & 0.097 & 0.183 & 48,532 & 0.060 & 0.093 & 0.142 & 19,066 & 0.059 & 0.100 & 0.205 & 29,466 \\
\hline \multicolumn{13}{|c|}{ OTHER DEPENDENT VARIABLES (Robustness) } \\
\hline NPL/TL & 0.019 & 0.011 & 0.025 & 48,532 & 0.021 & 0.015 & 0.024 & 19,066 & 0.018 & 0.009 & 0.256 & 29,466 \\
\hline$L L A / G T A$ & 0.009 & 0.008 & 0.006 & 48,532 & 0.010 & 0.009 & 0.006 & 19,066 & 0.009 & 0.008 & 0.006 & 29,466 \\
\hline \multicolumn{13}{|l|}{ Independent Pre-Crisis Variables } \\
\hline \multicolumn{13}{|l|}{ Key Independent Variables } \\
\hline COSTEFF & 0.500 & 0.495 & 0.173 & 48,532 & 0.505 & 0.502 & 0.169 & 19,066 & 0.497 & 0.491 & 0.175 & 29,466 \\
\hline PROFITEFF & 0.498 & 0.507 & 0.282 & 48,532 & 0.504 & 0.516 & 0.282 & 19,066 & 0.495 & 0.501 & 0.281 & 29,466 \\
\hline \multicolumn{13}{|l|}{ Basic Characteristics } \\
\hline COST EFF MOMENTUM & 0.596 & 0.500 & 0.535 & 48,532 & 0.781 & 0.579 & 0.747 & 19,066 & 0.475 & 0.429 & 0.273 & 29,466 \\
\hline PROFIT EFF MOMENTUM & 0.591 & 0.421 & 0.744 & 48,532 & 0.770 & 0.500 & 1.020 & 19,066 & 0.475 & 0.400 & 0.452 & 29,466 \\
\hline \multicolumn{13}{|l|}{ Other Bank Characteristics } \\
\hline \multicolumn{13}{|l|}{ A. Risk and Opacity } \\
\hline CAPITAL RATIO & 0.101 & 0.088 & 0.055 & 48,532 & 0.103 & 0.088 & 0.061 & 19,066 & 0.099 & 0.088 & 0.050 & 29,466 \\
\hline TOTAL LOANS / GTA & 0.557 & 0.573 & 0.148 & 48,532 & 0.566 & 0.580 & 0.156 & 19,066 & 0.552 & 0.569 & 0.142 & 29,466 \\
\hline COMMERCIAL RE RATIO & 0.146 & 0.120 & 0.111 & 48,532 & 0.165 & 0.131 & 0.130 & 19,066 & 0.133 & 0.115 & 0.094 & 29,466 \\
\hline BROKERED DEPOSITS RATIO & 0.007 & 0.000 & 0.042 & 48,532 & 0.011 & 0.000 & 0.060 & 19,066 & 0.004 & 0.000 & 0.025 & 29,466 \\
\hline UNUSED COMMITMENTS RATIO & 0.075 & 0.041 & 0.662 & 48,532 & 0.075 & 0.042 & 0.436 & 19,066 & 0.075 & 0.041 & 0.774 & 29,466 \\
\hline CASH HOLDINGS RATIO & 0.070 & 0.053 & 0.056 & 48,532 & 0.070 & 0.054 & 0.057 & 19,066 & 0.069 & 0.052 & 0.055 & 29,466 \\
\hline$L L A / G T A$ & 0.009 & 0.008 & 0.005 & 48,532 & 0.009 & 0.008 & 0.005 & 19,066 & 0.008 & 0.008 & 0.005 & 29,466 \\
\hline $\begin{array}{l}\text { LOAN CONCENTRATION } \\
\text { B. Size and Safety Net Protection }\end{array}$ & 0.316 & 0.290 & 0.099 & 48,532 & 0.325 & 0.296 & 0.106 & 19,066 & 0.310 & 0.287 & 0.093 & 29,466 \\
\hline$L N(G T A)$ & 11.454 & 11.308 & 1.243 & 48,532 & 11.504 & 11.352 & 1.270 & 19,066 & 11.422 & 11.279 & 1.224 & 29,466 \\
\hline SUPERVISOR OCC & 0.297 & 0.000 & 0.454 & 48,532 & 0.289 & 0.000 & 0.451 & 19,066 & 0.302 & 0.000 & 0.457 & 29,466 \\
\hline SUPERVISOR FDIC & 0.609 & 1.000 & 0.485 & 48,532 & 0.617 & 1.000 & 0.483 & 19,066 & 0.604 & 1.000 & 0.486 & 29,466 \\
\hline \multicolumn{5}{|l|}{ C. Bank Ownership } & 0.094 & 0.000 & 0.289 & 19,066 & 0.094 & 0.000 & 0.287 & 29,466 \\
\hline BHC MEMBER & 0.721 & 1.000 & 0.436 & 48,532 & 0.728 & 1.000 & 0.433 & 19,066 & 0.716 & 1.000 & 0.437 & 29,466 \\
\hline PUBLICLY LISTED & 0.115 & 0.000 & 0.309 & 48,532 & 0.120 & 0.000 & 0.317 & 19,066 & 0.112 & 0.000 & 0.304 & 29,466 \\
\hline $\begin{array}{l}\text { FOREIGN OWNERSHIP } \\
\text { D. Organizational Structure } \\
\end{array}$ & 0.009 & 0.000 & 0.088 & 48,532 & 0.008 & 0.000 & 0.084 & 19,066 & 0.009 & 0.000 & 0.090 & 29,466 \\
\hline BRANCHES / GTA & 0.030 & 0.024 & 0.024 & 48,532 & 0.030 & 0.024 & 0.024 & 19,066 & 0.030 & 0.024 & 0.023 & 29,466 \\
\hline $\begin{array}{l}\text { LN (NUMBER STATES }) \\
\text { E. Competition }\end{array}$ & 0.012 & 0.000 & 0.107 & 48,532 & 0.017 & 0.000 & 0.131 & 19,066 & 0.008 & 0.000 & 0.089 & 29,466 \\
\hline$\overline{\text { HHI DEPOSITS }}$ & 0.086 & 0.059 & 0.087 & 48,532 & 0.092 & 0.073 & 0.086 & 19,066 & 0.083 & 0.052 & 0.087 & 29,466 \\
\hline $\begin{array}{l}\text { PERCENT METROPOLITAN } \\
\text { F. Local Economic Conditions }\end{array}$ & 0.466 & 0.204 & 0.477 & 48,532 & 0.505 & 0.526 & 0.465 & 19,066 & 0.440 & 0.000 & 0.483 & 29,466 \\
\hline CHANGE COINCIDENT INDEX & 0.206 & 0.272 & 0.544 & 48,532 & -0.008 & 0.041 & 0.276 & 19,066 & 0.345 & 0.514 & 0.624 & 29,466 \\
\hline $\begin{array}{l}\text { HOUSE PRICE INFLATION } \\
\text { G. Other Variables (Robustness) }\end{array}$ & 0.426 & 0.450 & 1.006 & 48,532 & 0.313 & 0.281 & 0.934 & 19,066 & 0.499 & 0.570 & 1.044 & 29,466 \\
\hline $\begin{array}{l}\text { Enforcement Actions against } \\
\text { Management }\end{array}$ & 0.056 & 0.000 & 1.594 & 48,532 & 0.087 & 0.000 & 2.471 & 19,066 & 0.035 & 0.000 & 0.483 & 29,466 \\
\hline COST-TO-INCOME & 3.949 & 5.962 & 425.725 & 48,532 & 7.116 & 6.265 & 204.696 & 19,066 & 1.901 & 5.805 & 520.957 & 29,466 \\
\hline COST-TO-INCOME RANK & 0.500 & 0.500 & 0.289 & 48,532 & 0.500 & 0.500 & 0.289 & 19,066 & 0.500 & 0.500 & 0.288 & 29,466 \\
\hline
\end{tabular}




\section{Table 2: Do Cost and Profit Efficiency Protect Banks from Failing during Financial Crises? - Main Results} (All Crises)

This table reports estimates from regression estimates for analyzing whether cost and profit efficiency protect banks from failure during financial crises. Panel A presents the estimates using minimal controls, while Panel B presents the results using all controls. The dependent variables are FAILED1 and FAILED2. FAILED1 is a dummy equal to 1 during a crisis if the bank failed anytime during the crisis or of the bank became insolvent (capitalization ratio is less or equal to 2\%). FAILED2 is a dummy equal to 1 during a crisis if the bank failed anytime during the crisis. All independent variables are measured as averages over the pre-crisis periods. The key explanatory variables are cost efficiency COSTEFF and profit efficiency PROFITEFF. COST EFF MOMENTUM is the proportion of cost efficiency increases. PROFIT EFF MOMENTUM is the proportion of profit efficiency increases. $L N(G T A)$ is bank size calculated as the natural $\log$ of GTA.CAPITAL RATIO is bank capitalization, defined as the bank's total equity divided by GTA. TOTAL LOANS / GTA is the ratio of total loans to GTA. BHC MEMBER is a dummy variable that equals one if the bank was part of a BHC at any time in the pre-crisis period. COMMERCIAL RE RATIO is the commercial real estate loans divided by GTA. SUPERVISOR_OCC and SUPERVISOR_FDIC are dummies that equal 1 if the OCC and FDIC are the primary supervisor of the bank, respectively; both dummies are used in regressions (left out category: SUPERVISOR_FRSS). FOREIGN OWNERSHIP is a dummy equal to 1 if a bank has $50 \%$ or more foreign ownership. BROKERED DEPOSITS RATIO is brokered deposits divided by GTA. UNUSED COMMITMENTS RATIO is unused commitments divided by GTA. CASH HOLDINGS RATIO is cash holdings divided by GTA. LLA / GTA is loan loss allowance divided by GTA. HHI DEPOSITS is the bank-level Herfindahl-Hirschman Index (HHI) of deposit concentration for the local markets in which the bank is present. PERCENT METROPOLITAN is the percentage of bank deposits in metropolitan markets (MSAs and CBSAs) as a fraction of deposits in all markets in which a bank is active. BRANCHES / GTA is a measure of bank organizational complexity calculated as (ratio of the number of branches the bank has active over GTA) x 1000. LN (NUMBER STATES) is the natural log of the number of states in which bank has branches. PUBLICLY LISTED is a dummy equal to 1 if a bank is listed or is part of a BHC that is listed on a stock exchange. CHANGE COINCIDENT INDEX is the weighted average of the changes in the Philadelphia Federal Reserve's state coincident indexes with the share of the deposits of a given bank taken as weights. HOUSE PRICE INFLATION is the weighted average growth in a state-level house price index with the share of the deposits of a given bank taken as weights. LOAN CONCENTRATION is a bank's loan portfolio concentration is measured as a Herfindahl-Hirschman Index (HHI) of the following six loan categories: commercial real estate, residential real estate, construction and industrial, consumer, agriculture, and other loans. All variables are defined in Table 1. Robust $t$-statistics adjusted for bank clustering are reported in parentheses. ${ }^{*}, * *$, and ${ }^{* * *}$ denote significance at $10 \%, 5 \%$, and $1 \%$ level.

Panel A - Failure with Minimal Controls

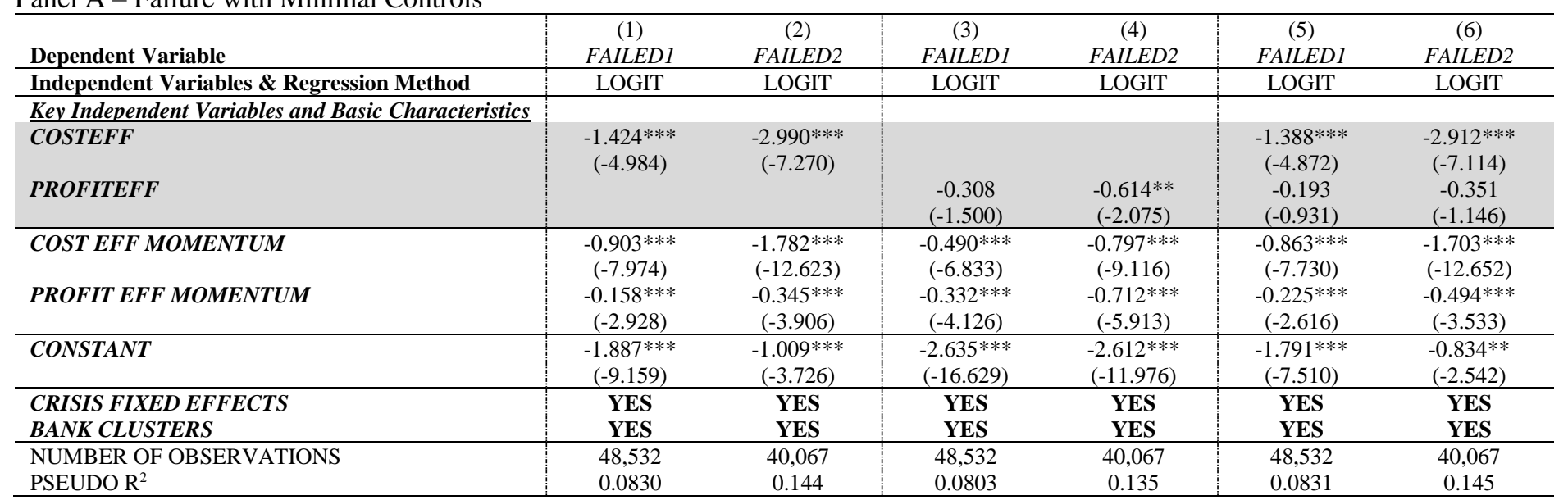

Panel B - Failure with All Controls

\begin{tabular}{|c|c|c|c|c|c|c|}
\hline Dependent Variable & $\begin{array}{c}(1) \\
\text { FAILED1 }\end{array}$ & $\begin{array}{c}(2) \\
F A I L E D 2\end{array}$ & $\begin{array}{c}(3) \\
\text { FAILED1 }\end{array}$ & $\begin{array}{c}(4) \\
\text { FAILED2 }\end{array}$ & $\begin{array}{c}\text { (5) } \\
\text { FAILED1 }\end{array}$ & $\begin{array}{c}(6) \\
\text { FAILED2 }\end{array}$ \\
\hline Independent Variables \& Regression Method & LOGIT & LOGIT & LOGIT & LOGIT & LOGIT & LOGIT \\
\hline \multicolumn{7}{|l|}{ Key Independent Variables and Basic Characteristics } \\
\hline $\begin{array}{l}\text { COSTEFF } \\
\text { PROFITEFF }\end{array}$ & $\begin{array}{c}-1.273 * * * \\
(-3.751)\end{array}$ & $\begin{array}{c}-3.557 * * * \\
(-7.263)\end{array}$ & $\begin{array}{c}-0.492 * * \\
(-2.121)\end{array}$ & $\begin{array}{c}-1.001 * * * \\
(-3.192)\end{array}$ & $\begin{array}{c}-1.183 * * * \\
(-3.526) \\
-0.370 \\
(-1.576)\end{array}$ & $\begin{array}{c}-3.367 * * * \\
(-6.853) \\
-0.645 * \\
(-1.906)\end{array}$ \\
\hline $\begin{array}{l}\text { COST EFF MOMENTUM } \\
\text { PROFIT EFF MOMENTUM }\end{array}$ & $\begin{array}{c}-0.889 * * * \\
(-6.306) \\
-0.154 * * * \\
(-2.581) \\
\end{array}$ & $\begin{array}{c}-2.147 * * * \\
(-10.553) \\
-0.301 * * * \\
(-3.198) \\
\end{array}$ & $\begin{array}{c}-0.468 * * * \\
(-5.297) \\
-0.386 * * * \\
(-4.014) \\
\end{array}$ & $\begin{array}{c}-0.820 * * * \\
(-7.785) \\
-0.844 * * * \\
(-5.813) \\
\end{array}$ & $\begin{array}{c}-0.803 * * * \\
(-5.757) \\
-0.287 * * * \\
(-2.820) \\
\end{array}$ & $\begin{array}{c}-1.983 * * * \\
(-10.063) \\
-0.590 * * * \\
(-3.395) \\
\end{array}$ \\
\hline \multicolumn{7}{|l|}{ Other Bank Characteristics: } \\
\hline A. Risk and Opacity & & & & & & \\
\hline
\end{tabular}




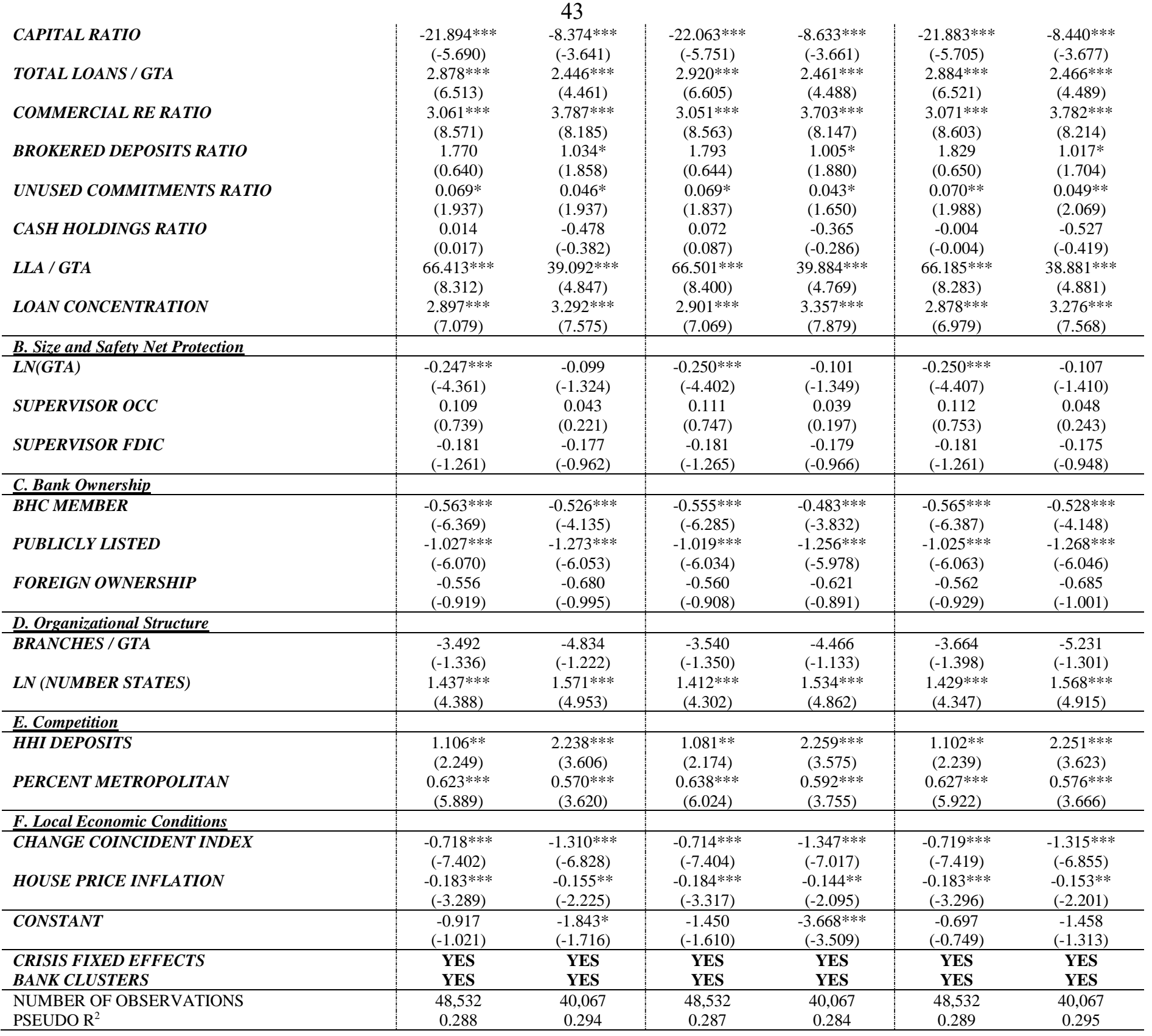


Table 3 - How Do Cost and Profit Efficiency during Normal Times Impact Bank Risk During Financial Crises? (All Crises)

This table reports estimates from regression estimates for analyzing how does cost and profit efficiency during normal times impact bank risk during financial crises. Panel A presents the estimates using minimal controls, while Panel B presents the results using all controls. The dependent variables are as follows: $L N(Z S C O R E$ ) is the log of the sum of a bank's mean ROA (net income over GTA) and mean CAPITAL RATIO (equity capital over GTA) divided by $\sigma R O A$ (the volatility of ROA), where the means of the components are calculated over the crises periods. $\sigma R O A$ is the volatility of return on assets $R O A$ over the crises periods. All independent variables are measured as averages over the pre-crisis periods. The key explanatory variables are cost efficiency COSTEFF and profit efficiency PROFITEFF. COST EFF MOMENTUM is the proportion of cost efficiency increases. PROFIT EFF MOMENTUM is the proportion of profit efficiency increases. $L N(G T A)$ is bank size calculated as the natural log of GTA.CAPITAL RATIO is bank capitalization, defined as the bank's total equity divided by GTA. TOTAL LOANS / GTA is the ratio of total loans to GTA. BHC MEMBER is a dummy variable that equals one if the bank was part of a $\mathrm{BHC}$ at any time in the pre-crisis period. COMMERCIAL RE RATIO is the commercial real estate loans divided by GTA. SUPERVISOR_OCC and SUPERVISOR_FDIC are dummies that equal 1 if the OCC and FDIC are the primary supervisor of the bank, respectively; both dummies are used in regressions (left out category: SUPERVISOR_FRS). FOREIGN OWNERSHIP is a dummy equal to 1 if a bank has $50 \%$ or more foreign ownership. BROKERED DEPOSITS RATIO is brokered deposits divided by GTA. UNUSED COMMITMENTS RATIO is unused commitments divided by GTA. CASH HOLDINGS RATIO is cash holdings divided by GTA. LLA / GTA is loan loss allowance divided by GTA. HHI DEPOSITS is the bank-level Herfindahl-Hirschman Index (HHI) of deposit concentration for the local markets in which the bank is present. PERCENT METROPOLITAN is the percentage of bank deposits in metropolitan markets (MSAs and CBSAs) as a fraction of deposits in all markets a bank is active. BRANCHES / GTA is a measure of bank organizational complexity calculated as (ratio of the number of branches the bank has active over GTA) $\mathrm{x}$ 1000. LN (NUMBER STATES) is the natural log of the number of states in which bank has branches. PUBLICLY LISTED is a dummy equal to 1 if a bank is listed or is part of a BHC that is listed on a stock exchange. CHANGE COINCIDENT INDEX is the weighted average of the changes in the Philadelphia Federal Reserve's state coincident indexes with the share of the deposits of a given bank taken as weights. HOUSE PRICE INFLATION is the weighted average growth in a state-level house price index with the share of the deposits of a given bank taken as weights. LOAN CONCENTRATION is a bank's loan portfolio concentration is measured as a Herfindahl-Hirschman Index (HHI) of the following six loan categories: commercial real estate, residential real estate, construction and industrial, consumer, agriculture, and other loans. All variables are defined in Table 1. Robust $t$-statistics adjusted for bank clustering are reported in parentheses. $* * *$, and $* * *$ denote significance at $10 \%, 5 \%$, and $1 \%$ level.

Panel A - Risk with Minimal Controls

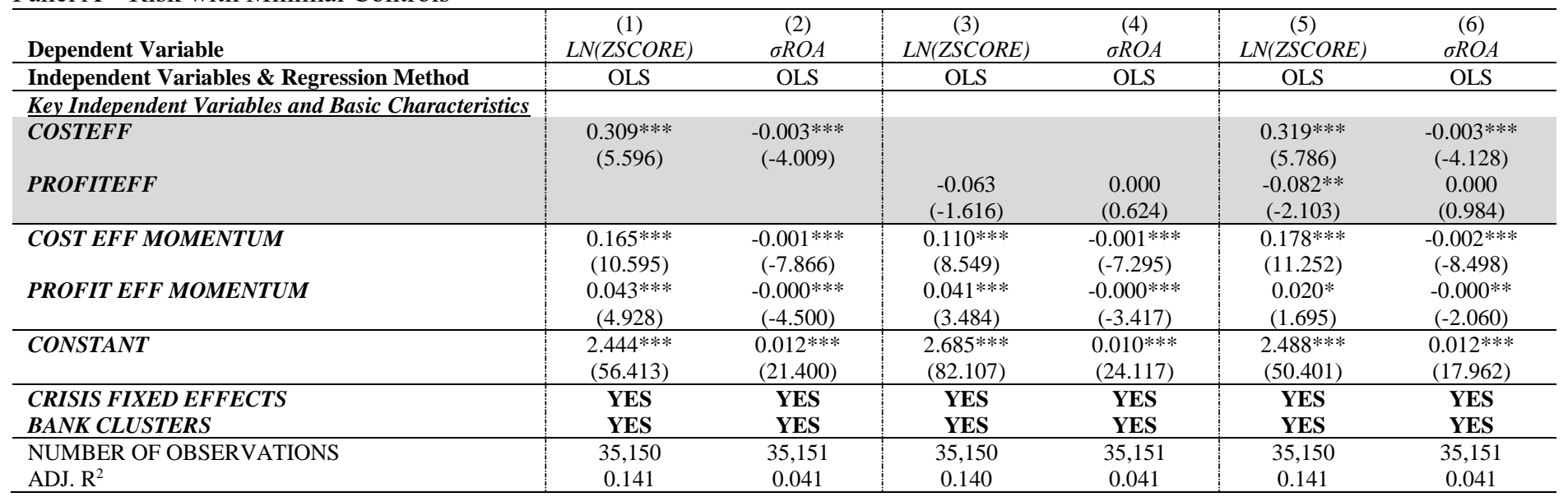

$\underline{\text { Panel B - Risk with All Controls }}$

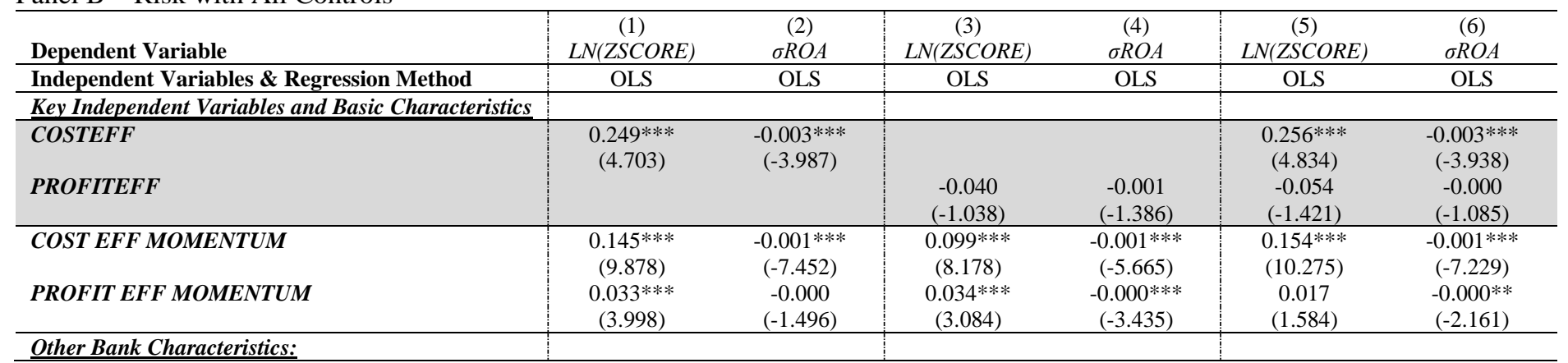




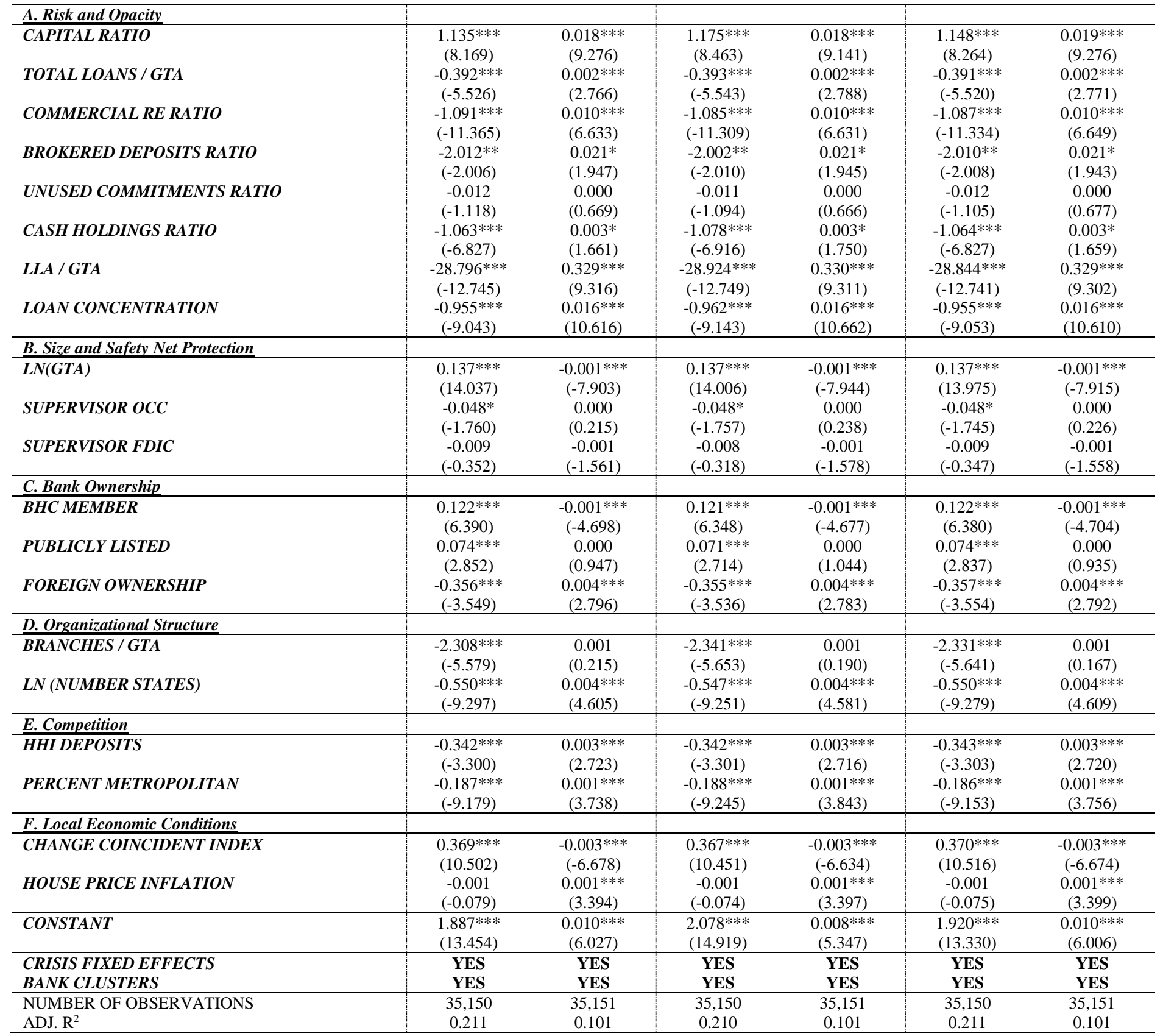


Table 4 - How Do Cost and Profit Efficiency during Normal Times Impact Bank Profitability during Financial Crises? (All Crises)

This table reports estimates from regression estimates for analyzing how does cost and profit efficiency during normal times impact bank profitability during financial crises. Panel A presents the estimates using minimal controls, while Panel B presents the results using all controls. The dependent variables are as follows: $R O A$ is the bank return on assets over the crises periods. ROE is the bank return on equity over the crises periods. All independent variables are measured as averages over the pre-crisis periods. The key explanatory variables are cost efficiency COSTEFF and profit efficiency PROFITEFF. COST EFF MOMENTUM is the proportion of cost efficiency increases. PROFIT EFF MOMENTUM is the proportion of profit efficiency increases. $L N(G T A)$ is bank size calculated as the natural $\log$ of GTA.CAPITAL RATIO is bank capitalization, defined as the bank's total equity divided by GTA. TOTAL LOANS / GTA is the ratio of total loans to GTA. BHC MEMBER is a dummy variable that equals one if the bank was part of a BHC at any time in the pre-crisis period. COMMERCIAL RE RATIO is the commercial real estate loans divided by GTA. SUPERVISOR_OCC and SUPERVISOR_FDIC are dummies that equal 1 if the OCC and FDIC are the primary supervisor of the bank, respectively; both dummies are used in regressions (left out category: SUPERVISOR_FRS). FOREIGN OWNERSHIP is a dummy equal to 1 if a bank has $50 \%$ or more foreign ownership. BROKERED DEPOSITS RATIO is brokered deposits divided by GTA. UNUSED COMMITMENTS RATIO is unused commitments divided by GTA. CASH HOLDINGS RATIO is cash holdings divided by GTA. LLA / GTA is loan loss allowance divided by GTA. HHI DEPOSITS is the bank-level Herfindahl-Hirschman Index (HHI) of deposit concentration for the local markets in which the bank is present. PERCENT METROPOLITAN is the percentage of bank deposits in metropolitan markets (MSAs and CBSAs) as a fraction of deposits in all markets in which a bank is active. BRANCHES / GTA is a measure of bank organizational complexity calculated as (ratio of the number of branches the bank has active over GTA) x 1000. LN (NUMBER STATES) is the natural log of the number of states in which bank has branches. PUBLICLY LISTED is a dummy equal to 1 if a bank is listed or is part of a BHC that is listed on a stock exchange. CHANGE COINCIDENT INDEX is the weighted average of the changes in the Philadelphia Federal Reserve's state coincident indexes with the share of the deposits of a given bank taken as weights. HOUSE PRICE INFLATION is the weighted average growth in a state-level house price index with the share of the deposits of a given bank taken as weights. LOAN CONCENTRATION is a bank's loan portfolio concentration is measured as a Herfindahl-Hirschman Index (HHI) of the following six loan categories: commercial real estate, residential real estate, construction and industrial, consumer, agriculture, and other loans. All variables are defined in Table 1. Robust $t$-statistics adjusted for bank clustering are reported in parentheses. *, $* *$, and $* * *$ denote significance at $10 \%, 5 \%$, and $1 \%$ level.

$\underline{\text { Panel A - Profitability with Minimal Controls }}$

\begin{tabular}{|c|c|c|c|c|c|c|}
\hline Dependent Variable & $\begin{array}{c}(1) \\
R O A\end{array}$ & $\begin{array}{c}(2) \\
R O E\end{array}$ & $\begin{array}{c}(3) \\
R O A\end{array}$ & $\begin{array}{c}(4) \\
R O E\end{array}$ & $\begin{array}{c}(5) \\
R O A \\
\end{array}$ & $\begin{array}{c}(6) \\
R O E\end{array}$ \\
\hline Independent Variables \& Regression Method & OLS & OLS & OLS & OLS & OLS & OLS \\
\hline \multicolumn{7}{|l|}{ Key Independent Variables and Basic Characteristics } \\
\hline COSTEFF & $\begin{array}{c}0.002 * * * \\
(3.176)\end{array}$ & $\begin{array}{c}0.019 * * * \\
(2.961)\end{array}$ & & & $\begin{array}{c}0.002 * * * \\
(3.415)\end{array}$ & $\begin{array}{c}0.020 * * * \\
(3.209)\end{array}$ \\
\hline PROFITEFF & & & $\begin{array}{c}-0.001 * * * \\
(-2.694)\end{array}$ & $\begin{array}{c}-0.012 * * * \\
(-2.800)\end{array}$ & $\begin{array}{l}-0.002 * * * \\
(-2.964)\end{array}$ & $\begin{array}{c}-0.014 * * * \\
(-3.067)\end{array}$ \\
\hline COST EFF MOMENTUM & $\begin{array}{l}0.002^{* * * *} \\
(9.337)\end{array}$ & $\begin{array}{l}0.015^{* * * *} \\
(9.572)\end{array}$ & $\begin{array}{c}0.001 * * * \\
(8.897)\end{array}$ & $\begin{array}{c}0.013 * * * \\
(8.894)\end{array}$ & $\begin{array}{c}0.002 * * * \\
(10.535)\end{array}$ & $\begin{array}{c}0.018 * * * \\
(10.775)\end{array}$ \\
\hline PROFIT EFF MOMENTUM & $\begin{array}{c}0.001 * * * \\
(7.914)\end{array}$ & $\begin{array}{c}0.007 * * * \\
(7.392)\end{array}$ & $\begin{array}{c}0.001 * * * \\
(3.836)\end{array}$ & $\begin{array}{c}0.005 * * * \\
(3.692)\end{array}$ & $\begin{array}{c}0.000 * * \\
(2.499)\end{array}$ & $\begin{array}{l}0.003 * * \\
(2.503)\end{array}$ \\
\hline CONSTANT & $\begin{array}{c}0.004 * * * \\
(6.698) \\
\end{array}$ & $\begin{array}{c}0.049 * * * \\
(10.432) \\
\end{array}$ & $\begin{array}{l}0.006 * * * \\
(14.897) \\
\end{array}$ & $\begin{array}{c}0.069 * * * \\
(19.837) \\
\end{array}$ & $\begin{array}{c}0.004 * * * \\
(7.291) \\
\end{array}$ & $\begin{array}{r}0.056^{* * * *} \\
(10.609) \\
\end{array}$ \\
\hline $\begin{array}{l}\text { CRISIS FIXED EFFECTS } \\
\text { BANK CLUSTERS }\end{array}$ & $\begin{array}{l}\text { YES } \\
\text { YES }\end{array}$ & $\begin{array}{l}\text { YES } \\
\text { YES }\end{array}$ & $\begin{array}{l}\text { YES } \\
\text { YES }\end{array}$ & $\begin{array}{l}\text { YES } \\
\text { YES }\end{array}$ & $\begin{array}{l}\text { YES } \\
\text { YES }\end{array}$ & $\begin{array}{l}\text { YES } \\
\text { YES }\end{array}$ \\
\hline $\begin{array}{l}\text { NUMBER OF OBSERVATIONS } \\
\text { ADJ. } \text { R }^{2}\end{array}$ & $\begin{array}{c}48,532 \\
0.047\end{array}$ & $\begin{array}{c}48,532 \\
0.060\end{array}$ & $\begin{array}{c}48,532 \\
0.047\end{array}$ & $\begin{array}{c}48,532 \\
0.060\end{array}$ & $\begin{array}{c}48,532 \\
0.047\end{array}$ & $\begin{array}{c}48,532 \\
0.060\end{array}$ \\
\hline
\end{tabular}

$\underline{\text { Panel B - Profitability with All Controls }}$

\begin{tabular}{|c|c|c|c|c|c|c|}
\hline Dependent Variable & $\begin{array}{c}(1) \\
R O A\end{array}$ & $\begin{array}{c}(2) \\
R O E\end{array}$ & $\begin{array}{c}(3) \\
R O A\end{array}$ & $\begin{array}{c}\text { (4) } \\
R O E\end{array}$ & $\begin{array}{c}(5) \\
R O A\end{array}$ & $\begin{array}{c}(6) \\
R O E\end{array}$ \\
\hline Independent Variables \& Regression Method & OLS & OLS & OLS & OLS & OLS & OLS \\
\hline \multicolumn{7}{|l|}{ Key Independent Variables and Basic Characteristics } \\
\hline $\begin{array}{l}\text { COSTEFF } \\
\text { PROFITEFF }\end{array}$ & $\begin{array}{c}0.002 * * * \\
(3.614)\end{array}$ & $\begin{array}{c}0.023 * * * \\
(3.982)\end{array}$ & $\begin{array}{c}-0.001 \\
(-1.339)\end{array}$ & $\begin{array}{c}-0.005 \\
(-1.225)\end{array}$ & $\begin{array}{c}0.002 * * * \\
(3.745) \\
-0.001 \\
(-1.626)\end{array}$ & $\begin{array}{c}0.024 * * * \\
(4.108) \\
-0.006 \\
(-1.558)\end{array}$ \\
\hline $\begin{array}{l}\text { COST EFF MOMENTUM } \\
\text { PROFIT EFF MOMENTUM }\end{array}$ & $\begin{array}{c}0.001 * * * \\
(8.541) \\
0.001 * * * \\
(5.552)\end{array}$ & $\begin{array}{c}0.014 * * * \\
(9.458) \\
0.005 * * * \\
(5.557)\end{array}$ & $\begin{array}{c}0.001 * * * \\
(6.676) \\
0.000 * * * \\
(3.670)\end{array}$ & $\begin{array}{c}0.009 * * * \\
(7.071) \\
0.005 * * * \\
(4.191)\end{array}$ & $\begin{array}{c}0.002 * * * \\
(9.132) \\
0.000^{* *} * \\
(2.262)\end{array}$ & $\begin{array}{c}0.015 * * * \\
(9.940) \\
0.003 * * * \\
(2.717)\end{array}$ \\
\hline \multicolumn{7}{|l|}{ Other Bank Characteristics: } \\
\hline A. Risk and Opacity & & & & & & \\
\hline
\end{tabular}


CAPITAL RATIO

TOTAL LOANS / GTA

COMMERCIAL RE RATIO

BROKERED DEPOSITS RATIO

UNUSED COMMITMENTS RATIO

CASH HOLDINGS RATIO

LLA / GTA

LOAN CONCENTRATION

B. Size and Safety Net Protection

LN $(G T A)$

SUPERVISOR OCC

SUPERVISOR FDIC

C. Bank Ownership

BHC MEMBER

PUBLICLY LISTED

FOREIGN OWNERSHIP

D. Organizational Structure

BRANCHES / GTA

LN (NUMBER STATES)

E. Competition

HHI DEPOSITS

PERCENT METROPOLITAN

F. Local Economic Conditions

CHANGE COINCIDENT INDEX

HOUSE PRICE INFLATION

\begin{tabular}{l|c}
\hline F. Local Economic Conditions & \\
\hline CHANGE COINCIDENT INDEX & $0.006^{*}$ \\
& $(16.337)$ \\
HOUSE PRICE INFLATION & $0.001^{*}$ \\
& $(4.663$ \\
\hline CONSTANT & 0.003 \\
& $(1.746$ \\
\hline CRISIS FIXED EFFECTS & YES \\
BANK CLUSTERS & YES \\
\hline NUMBER OF OBSERVATIONS & 48,532 \\
ADJ. R & 2 \\
\hline
\end{tabular}

$-0.007 * *$

$(-7.045)$

$-0.013 * * *$

$(-9.419)$

$-0.021 * *$

$(-1.967)$

$0.000 * *$

(2.428)

$-0.003^{*}$

$(-1.650)$

$-0.233 * * *$

(-4.698)

$-0.007 * * *$

$(-5.177)$

$(-5.177)$

0.001 **

(2.161)

$0.002 * * *$

(4.194)

$0.002 * *$

(8.245)

$0.001 * * *$

(5.031)

$-0.004 * * *$

(-3.459)

$-0.042 *$
$(-6.764)$
$-0.004 *$

$(-5.822)$

0.002

(1.398)

$(-15.218)$

0.126

47

$-0.218 * *$

$(-12.955)$

$-0.045^{* * * *}$

(-5.666)

$0.001 * * * \quad 0.013 * * *$

$\begin{array}{ll}0.001 & \\ (7.807) & (11.140)\end{array}$

$(-4.848)$

$0.042 * * * \quad-0.233 * *$

$-0.004 * * *$

\begin{tabular}{c:cc:cc} 
& & & & \\
$-0.233 * * *$ & $-0.042 * * *$ & $-0.236 * * *$ & $-0.042 * * *$ & $-0.235 * * *$ \\
$(-4.556)$ & $(-6.808)$ & $(-4.612)$ & $(-6.802)$ & $(-4.600)$ \\
$-0.047 * * *$ & $-0.004 * * *$ & $-0.046 * * *$ & $-0.004 * * *$ & $-0.047 * * *$ \\
$(-7.274)$ & $(-5.791)$ & $(-7.242)$ & $(-5.816)$ & $(-7.265)$ \\
\hline & & & & \\
\hline 0.021 & 0.002 & $0.021 *$ & 0.002 & 0.021 \\
$(1.643)$ & $(1.406)$ & $(1.653)$ & $(1.395)$ & $(1.640)$ \\
$-0.041 * * *$ & $-0.004 * * *$ & $-0.041 * * *$ & $-0.004 * * *$ & $-0.041 * * *$ \\
$(-16.231)$ & $(-15.254)$ & $(-16.274)$ & $(-15.197)$ & $(-16.219)$ \\
\hline & & & & \\
\hline $0.079 * * *$ & $0.006 * * *$ & $0.079 * * *$ & $0.006 * * *$ & $0.079 * * *$ \\
$(24.258)$ & $(16.295)$ & $(24.212)$ & $(16.339)$ & $(24.260)$ \\
$0.007 * * *$ & $0.001 * * *$ & $0.007 * * *$ & $0.001 * * *$ & $0.007 * * *$ \\
$(5.741)$ & $(4.672)$ & $(5.748)$ & $(4.671)$ & $(5.747)$ \\
\hline 0.004 & $0.005 * * *$ & $0.024 *$ & $0.004 * *$ & 0.008 \\
$(0.296)$ & $(2.936)$ & $(1.655)$ & $(1.992)$ & $(0.555)$ \\
\hline YES & YES & YES & YES & YES \\
YES & YES & YES & YES & YES \\
\hline 48,532 & 48,532 & 48,532 & 48,532 & 48,532 \\
0.179 & 0.126 & 0.179 & 0.126 & 0.179 \\
& & & & \\
\hline & & & & \\
\hline & & & & \\
\hline & & & & \\
\hline
\end{tabular}


Table 5: Do Cost and Profit Efficiency Affect Bank Failure, Risk, and Profitability during Financial Crises? - Banking Crises and Market Crises Results

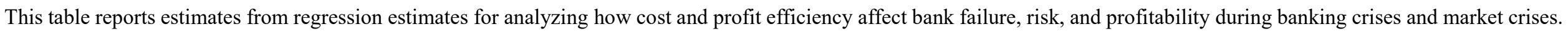

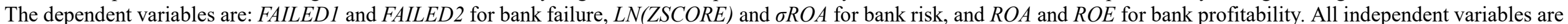

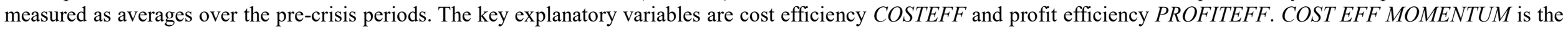

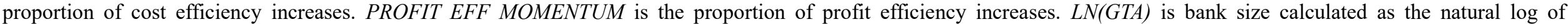

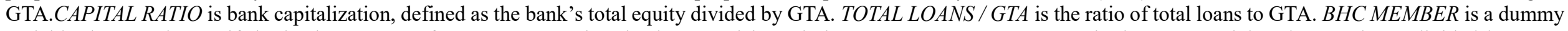

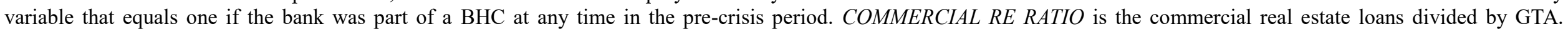

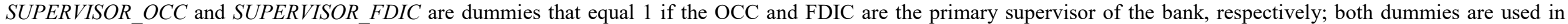

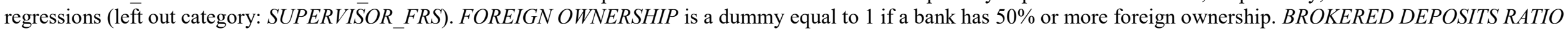

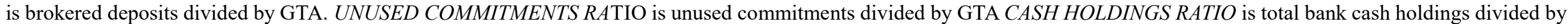

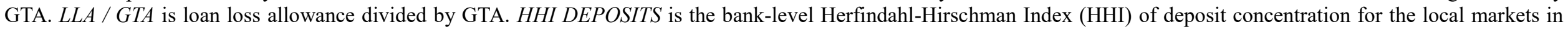

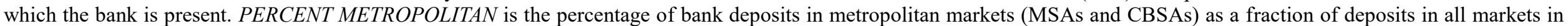

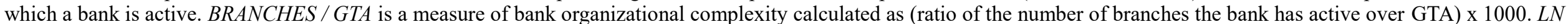

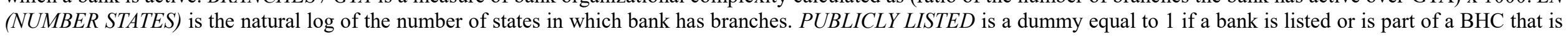

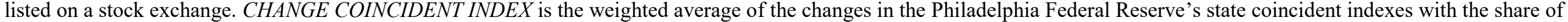

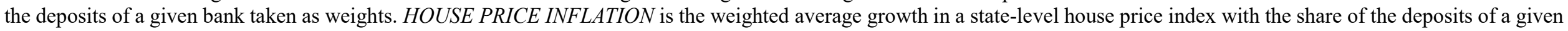

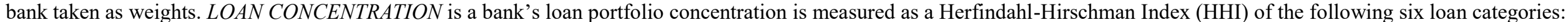

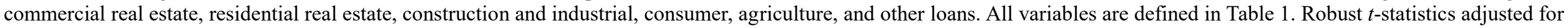
bank clustering are reported in parentheses. $* * *$, and $* * *$ denote significance at $10 \%, 5 \%$, and $1 \%$ level.

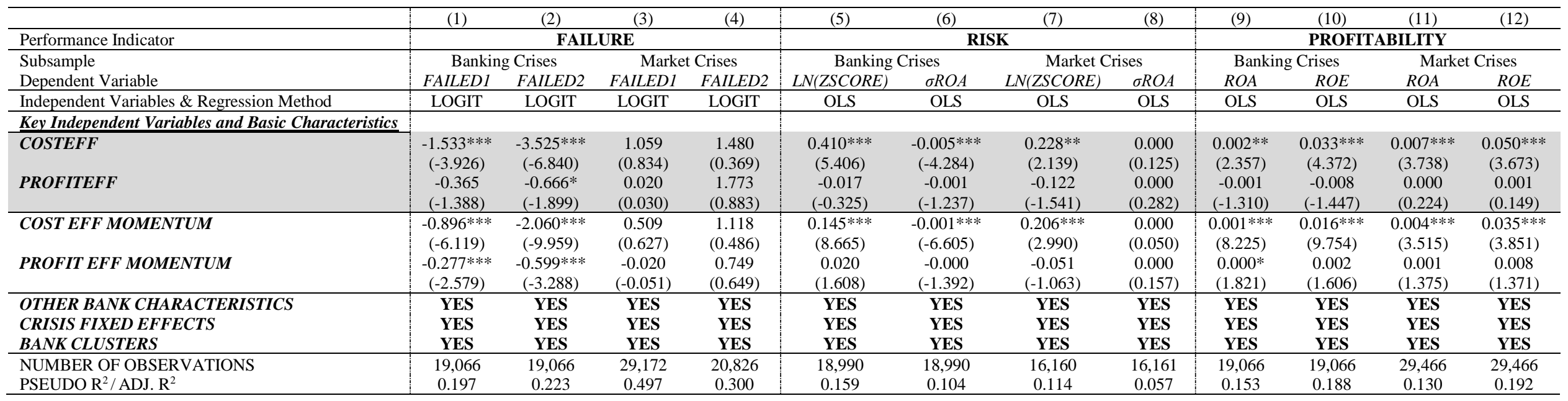


Table 6: Robustness - Excluding Too-Big-to-Fail (TBTF) Institutions

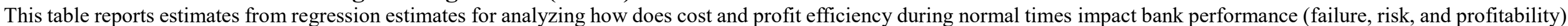

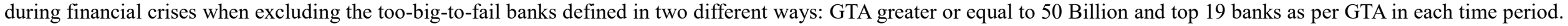

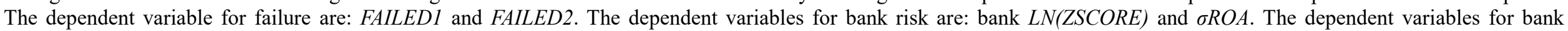

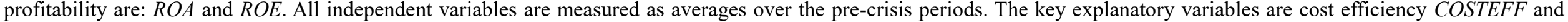

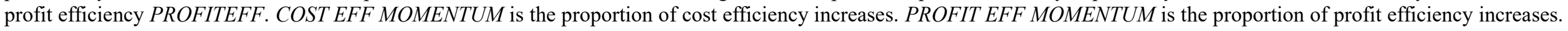

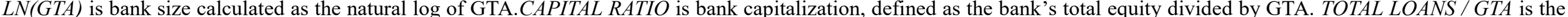

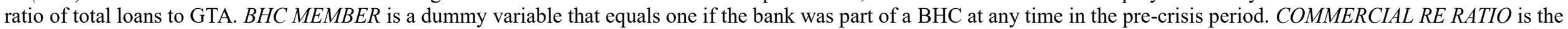

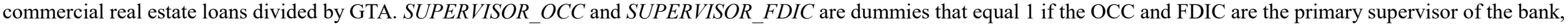

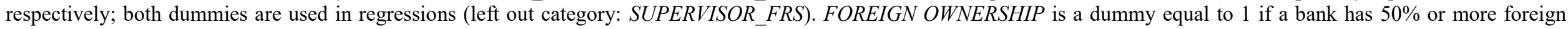

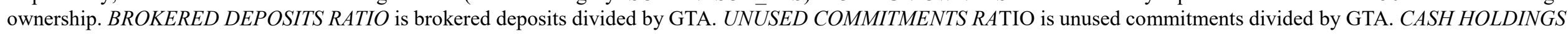

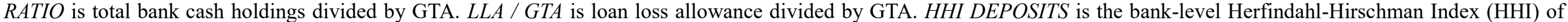

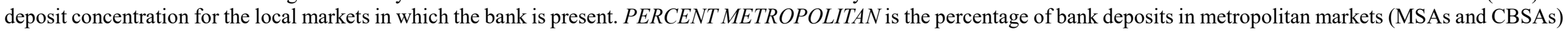

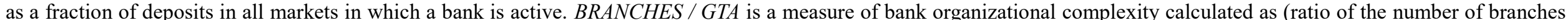

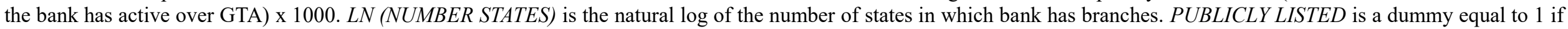

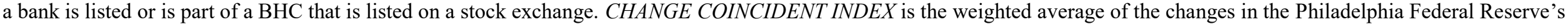

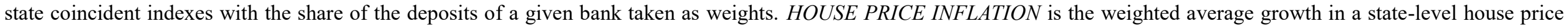

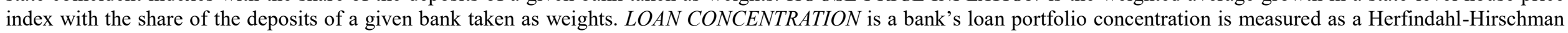

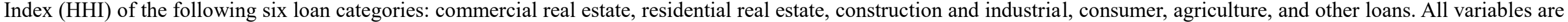
defined in Table 1 . Robust $t$-statistics adjusted for bank clustering are reported in parentheses. *, **, and *** denote significance at $10 \%, 5 \%$, and $1 \%$ level.

\begin{tabular}{|c|c|c|c|c|c|c|c|c|c|c|c|c|}
\hline & (1) & (2) & (3) & (4) & (5) & (6) & (7) & (8) & (9) & (10) & (11) & (12) \\
\hline Performance Indicator & \multicolumn{4}{|c|}{ FAILURE } & \multicolumn{4}{|c|}{ RISK } & \multicolumn{4}{|c|}{ PROFITABILITY } \\
\hline Test & \multicolumn{2}{|c|}{$\begin{array}{l}\text { Excluding Banks } \\
\text { with GTA } \\
\geq 50 \text { Billion } \\
\end{array}$} & \multicolumn{2}{|c|}{$\begin{array}{l}\text { Excluding top } 19 \text { banks } \\
\text { (per GTA) in each } \\
\text { time period }\end{array}$} & \multicolumn{2}{|c|}{$\begin{array}{l}\text { Excluding Banks } \\
\text { with GTA } \\
\geq 50 \text { Billion }\end{array}$} & \multicolumn{2}{|c|}{$\begin{array}{l}\text { Excluding top } 19 \text { banks } \\
\text { (per GTA) in each } \\
\text { time period }\end{array}$} & \multicolumn{2}{|c|}{$\begin{array}{l}\text { Excluding Banks } \\
\text { with GTA } \\
\geq 50 \text { Billion }\end{array}$} & \multicolumn{2}{|c|}{$\begin{array}{l}\text { Excluding top } 19 \text { banks } \\
\text { (per GTA) in each } \\
\text { time period }\end{array}$} \\
\hline Dependent Variable & FAILEDI & FAILED2 & FAILED1 & FAILED2 & $L N(Z S C O R E)$ & $\sigma R O A$ & $L N(Z S C O R E)$ & $\sigma R O A$ & $R O A$ & $R O E$ & $R O A$ & $R O E$ \\
\hline Independent Variables \& Regression Method & LOGIT & LOGIT & LOGIT & LOGIT & OLS & OLS & OLS & OLS & OLS & OLS & OLS & OLS \\
\hline \multicolumn{13}{|c|}{ Key Independent Variables and Basic Characteristics } \\
\hline $\begin{array}{l}\text { COSTEFF } \\
\text { PROFITEFF }\end{array}$ & $\begin{array}{c}-1.191 * * * \\
(-3.537) \\
-0.368 \\
(-1.558)\end{array}$ & $\begin{array}{c}-3.447 * * * \\
(-6.919) \\
-0.657 * \\
(-1.909)\end{array}$ & $\begin{array}{c}-1.177 * * * \\
(-3.501) \\
-0.382 \\
(-1.619) \\
\end{array}$ & $\begin{array}{c}-3.404 * * * \\
(-6.854) \\
-0.692 * * \\
(-2.006)\end{array}$ & $\begin{array}{c}0.258 * * * \\
(4.871) \\
-0.053 \\
(-1.397) \\
\end{array}$ & $\begin{array}{c}-0.003 * * * \\
(-3.868) \\
-0.000 \\
(-1.049) \\
\end{array}$ & $\begin{array}{c}0.259 * * * \\
(4.902) \\
-0.053 \\
(-1.406) \\
\end{array}$ & $\begin{array}{c}-0.003 * * * \\
(-3.887) \\
-0.000 \\
(-1.033) \\
\end{array}$ & $\begin{array}{c}0.002 * * * \\
(3.699) \\
-0.001 \\
(-1.607) \\
\end{array}$ & $\begin{array}{c}0.024 * * * \\
(4.074) \\
-0.006 \\
(-1.523)\end{array}$ & $\begin{array}{c}0.002 * * * \\
(3.689) \\
-0.001 \\
(-1.610)\end{array}$ & $\begin{array}{c}0.024 * * * \\
(4.057) \\
-0.006 \\
(-1.549) \\
\end{array}$ \\
\hline $\begin{array}{l}\text { COST EFF MOMENTUM } \\
\text { PROFIT EFF MOMENTUM }\end{array}$ & $\begin{array}{c}-0.804 * * * \\
(-5.743) \\
-0.291 * * * \\
(-2.839)\end{array}$ & $\begin{array}{c}-2.010 * * * \\
(-10.009) \\
-0.611 * * * \\
(-3.412)\end{array}$ & $\begin{array}{c}-0.800 * * * \\
(-5.725) \\
-0.294 * * * \\
(-2.867)\end{array}$ & $\begin{array}{c}-1.993 * * * \\
(-9.978) \\
-0.620 * * * \\
(-3.462)\end{array}$ & $\begin{array}{c}0.154 * * * \\
(10.303) \\
0.017 \\
(1.577)\end{array}$ & $\begin{array}{c}-0.001 * * * \\
(-7.237) \\
-0.000 * * \\
(-2.179)\end{array}$ & $\begin{array}{c}0.155^{* * *} \\
(10.318) \\
0.017 \\
(1.584)\end{array}$ & $\begin{array}{c}-0.001 * * * \\
(-7.254) \\
-0.000 * * \\
(-2.163)\end{array}$ & $\begin{array}{c}0.002 * * * \\
(9.110) \\
0.000 * * \\
(2.286)\end{array}$ & $\begin{array}{c}0.015 * * * \\
(9.926) \\
0.003 * * * \\
(2.753)\end{array}$ & $\begin{array}{c}0.002 * * * \\
(9.075) \\
0.000^{*} * \\
(2.305)\end{array}$ & $\begin{array}{c}0.015^{* * * *} \\
(9.833) \\
0.003^{* * * *} \\
(2.798)\end{array}$ \\
\hline $\begin{array}{l}\text { OTHER BANK CHARACTERISTICS } \\
\text { CRISIS FIXED EFFECTS } \\
\text { BANK CLUSTERS }\end{array}$ & $\begin{array}{l}\text { YES } \\
\text { YES } \\
\text { YES }\end{array}$ & $\begin{array}{l}\text { YES } \\
\text { YES } \\
\text { YES }\end{array}$ & $\begin{array}{l}\text { YES } \\
\text { YES } \\
\text { YES }\end{array}$ & $\begin{array}{l}\text { YES } \\
\text { YES } \\
\text { YES }\end{array}$ & $\begin{array}{l}\text { YES } \\
\text { YES } \\
\text { YES }\end{array}$ & $\begin{array}{l}\text { YES } \\
\text { YES } \\
\text { YES }\end{array}$ & $\begin{array}{l}\text { YES } \\
\text { YES } \\
\text { YES }\end{array}$ & $\begin{array}{l}\text { YES } \\
\text { YES } \\
\text { YES }\end{array}$ & $\begin{array}{l}\text { YES } \\
\text { YES } \\
\text { YES }\end{array}$ & $\begin{array}{l}\text { YES } \\
\text { YES } \\
\text { YES }\end{array}$ & $\begin{array}{l}\text { YES } \\
\text { YES } \\
\text { YES }\end{array}$ & $\begin{array}{l}\text { YES } \\
\text { YES } \\
\text { YES }\end{array}$ \\
\hline $\begin{array}{l}\text { NUMBER OF OBSERVATIONS } \\
\text { PSEUDO R }^{2} \text { / ADJ. R }{ }^{2}\end{array}$ & $\begin{array}{c}48,455 \\
0.292\end{array}$ & $\begin{array}{c}40,002 \\
0.299\end{array}$ & $\begin{array}{c}48,437 \\
0.292\end{array}$ & $\begin{array}{c}39,991 \\
0.298\end{array}$ & $\begin{array}{c}35,084 \\
0.211\end{array}$ & $\begin{array}{c}35,085 \\
0.101\end{array}$ & $\begin{array}{c}35,074 \\
0.211\end{array}$ & $\begin{array}{c}35,075 \\
0.101\end{array}$ & $\begin{array}{c}48,455 \\
0.126\end{array}$ & $\begin{array}{c}48,455 \\
0.179\end{array}$ & $\begin{array}{c}48,437 \\
0.126\end{array}$ & $\begin{array}{c}48,437 \\
0.180\end{array}$ \\
\hline
\end{tabular}


Table 7: Robustness - Controlling for Cost-to-Income

This table reports estimates from regression estimates for analyzing how does cost and profit efficiency during normal times impact bank performance (failure, risk, and profitability) during financial crises when controlling for COST-TO-INCOME in columns (1)-(6), and COST-TO-INCOME RANK in columns (7)-(12). The dependent variables for failure are FAILED1 and FAILURE2. The dependent variables for bank risk are: bank $L N(Z S C O R E)$ and $\sigma R O A$. The dependent variables for bank profitability are: ROA and ROE. All independent variables are measured as averages over the pre-crisis periods. The key explanatory variables are cost efficiency COSTEFF and profit efficiency PROFITEFF. COST EFF MOMENTUM is the proportion of cost efficiency increases. PROFIT EFF MOMENTUM is the proportion of profit efficiency increases. $L N(G T A)$ is bank size calculated as the natural log of GTA.CAPITAL RATIO is bank capitalization, defined as the bank's total equity divided by GTA. TOTAL LOANS / GTA is the ratio of total loans to GTA. BHC MEMBER is a dummy variable that equals one if the bank was part of a BHC at any time in the pre-crisis period. COMMERCIAL RE RATIO is the commercial real estate loans divided by GTA. SUPERVISOR_OCC and SUPERVISOR_FDIC are dummies that equal 1 if the OCC and FDIC are the primary supervisor of the bank, respectively; both dummies are used in regressions (left out category: SUPERVISOR_FRS). FOREIGN OWNERSHIP is a dummy equal to 1 if a bank has 50\% or more foreign ownership. BROKERED DEPOSITS RATIO is brokered deposits divided by GTA. UNUSED COMMITMENTS RATIO is unused commitments divided by GTA. CASH HOLDINGS RATIO is total bank cash holdings divided by GTA. LLA / GTA is loan loss allowance divided by GTA. HHI DEPOSITS is the bank-level Herfindahl-Hirschman Index (HHI) of deposit concentration for the local markets in which the bank is present. PERCENT METROPOLITAN is the percentage of bank deposits in metropolitan markets (MSAs and CBSAs) as a fraction of deposits in all markets in which a bank is active. BRANCHES / GTA is a measure of bank organizational complexity calculated as (ratio of the number of branches the bank has active over GTA) $\mathrm{x} 1000.2 N$ (NUMBER STATES) is the natural log of the number of states in which bank has branches. PUBLICLY LISTED is a dummy equal to 1 if a bank is listed or is part of a BHC that is listed on a stock exchange. CHANGE COINCIDENT INDEX is the weighted average of the changes in the Philadelphia Federal Reserve's state coincident indexes with the share of the deposits of a given bank taken as weights. HOUSE PRICE INFLATION is the weighted average growth in a state-level house price index with the share of the deposits of a given bank taken as weights. LOAN CONCENTRATION is a bank's loan portfolio concentration is measured as a Herfindahl-Hirschman Index (HHI) of the following six loan categories: commercial real estate, residential real estate, construction and industrial, consumer, agriculture, and other loans. All variables are defined in Table 1 . Robust $t$-statistics adjusted for bank clustering are reported in parentheses. ${ }^{*}, *$, and $* * *$ denote significance at $10 \%, 5 \%$, and $1 \%$ level.

\begin{tabular}{|c|c|c|c|c|c|c|c|c|c|c|c|c|}
\hline \multirow{4}{*}{$\begin{array}{l}\text { Test: } \\
\text { Performance Indicator } \\
\text { Dependent Variable }\end{array}$} & \multicolumn{6}{|c|}{ Controlling for Cost-to-Income (Level) } & \multicolumn{6}{|c|}{ Controlling for Cost-to-Income Rank } \\
\hline & (1) & (2) & (3) & (4) & (5) & (6) & (7) & (8) & (9) & (10) & (11) & (12) \\
\hline & \multicolumn{2}{|c|}{ FAILURE } & \multicolumn{2}{|c|}{ RISK } & \multicolumn{2}{|c|}{ PROFITABILITY } & \multicolumn{2}{|c|}{ FAILURE } & \multicolumn{2}{|c|}{ RISK } & \multicolumn{2}{|c|}{ PROFITABILITY } \\
\hline & FAILED1 & FAILED2 & $L N(Z S C O R E)$ & $\sigma R O A$ & $R O A$ & $R O E$ & FAILED1 & FAILED2 & $L N(Z S C O R E)$ & $\sigma R O A$ & $R O A$ & $R O E$ \\
\hline Independent Variables \& Regression Method & LOGIT & LOGIT & OLS & OLS & OLS & OLS & LOGIT & LOGIT & OLS & OLS & OLS & OLS \\
\hline \multicolumn{13}{|c|}{ Kev Independent Variables and Basic Characteristics } \\
\hline $\begin{array}{l}\text { COSTEFF } \\
\text { PROFITEFF }\end{array}$ & $\begin{array}{c}-1.182 * * * \\
(-3.525) \\
-0.370 \\
(-1.575) \\
\end{array}$ & $\begin{array}{c}-3.367 * * * \\
(-6.853) \\
-0.645 * \\
(-1.906) \\
\end{array}$ & $\begin{array}{c}0.256 \text { *** } \\
(4.834) \\
-0.054 \\
(-1.421) \\
\end{array}$ & $\begin{array}{c}-0.003 * * * \\
(-3.938) \\
-0.000 \\
(-1.085) \\
\end{array}$ & $\begin{array}{c}0.002 * * * \\
(3.742) \\
-0.001 \\
(-1.622) \\
\end{array}$ & $\begin{array}{c}0.024 * * * \\
(4.103) \\
-0.006 \\
(-1.553) \\
\end{array}$ & $\begin{array}{c}-1.048 * * * \\
(-3.147) \\
-0.298 \\
(-1.253) \\
\end{array}$ & $\begin{array}{c}-3.149 * * * \\
(-6.543) \\
-0.560 \\
(-1.630) \\
\end{array}$ & $\begin{array}{c}0.253 * * * \\
(4.798) \\
-0.057 \\
(-1.511) \\
\end{array}$ & $\begin{array}{c}-0.003 * * * \\
(-3.914) \\
-0.000 \\
(-1.004) \\
\end{array}$ & $\begin{array}{c}0.003 * * * \\
(3.755) \\
-0.001 \\
(-1.620) \\
\end{array}$ & $\begin{array}{c}0.024 * * * \\
(4.056) \\
-0.007 \\
(-1.613) \\
\end{array}$ \\
\hline $\begin{array}{l}\text { COST EFF MOMENTUM } \\
\text { PROFIT EFF MOMENTUM }\end{array}$ & $\begin{array}{c}-0.803 * * * \\
(-5.755) \\
-0.287 * * * \\
(-2.820) \\
\end{array}$ & $\begin{array}{c}-1.983 * * * \\
(-10.064) \\
-0.590 * * * \\
(-3.395) \\
\end{array}$ & $\begin{array}{c}0.154 * * * \\
(10.275) \\
0.017 \\
(1.584) \\
\end{array}$ & $\begin{array}{c}-0.001 * * * \\
(-7.230) \\
-0.000 * * \\
(-2.161) \\
\end{array}$ & $\begin{array}{c}0.002 * * * \\
(9.128) \\
0.000 * * \\
(2.266) \\
\end{array}$ & $\begin{array}{c}0.015 * * * \\
(9.935) \\
0.003 * * * \\
(2.724) \\
\end{array}$ & $\begin{array}{c}-0.765 * * * \\
(-5.630) \\
-0.283 * * * \\
(-2.788) \\
\end{array}$ & $\begin{array}{c}-1.893 * * * \\
(-10.188) \\
-0.590 * * * \\
(-3.372) \\
\end{array}$ & $\begin{array}{c}0.153 * * * \\
(10.220) \\
0.017 \\
(1.541) \\
\end{array}$ & $\begin{array}{c}-0.001 * * * \\
(-7.203) \\
-0.000 * * \\
(-2.120) \\
\end{array}$ & $\begin{array}{c}0.002 * * * \\
(9.164) \\
0.000 * * \\
(2.266) \\
\end{array}$ & $\begin{array}{c}0.015 * * * \\
(9.852) \\
0.003 * * * \\
(2.678) \\
\end{array}$ \\
\hline COST-TO-INCOME & $\begin{array}{c}-0.000 \\
(-0.384) \\
\end{array}$ & $\begin{array}{c}-0.000 \\
(-0.013) \\
\end{array}$ & $\begin{array}{c}0.000 \\
(0.315) \\
\end{array}$ & $\begin{array}{c}0.000 \\
(0.245) \\
\end{array}$ & $\begin{array}{l}0.000^{*} \\
(1.851)\end{array}$ & $\begin{array}{l}0.000^{*} \\
(1.662) \\
\end{array}$ & & & & & & \\
\hline COST-TO-INCOME RANK & & & & & & & $\begin{array}{l}1.836 * * * \\
(11.869) \\
\end{array}$ & $\begin{array}{c}1.647 * * * \\
(7.358) \\
\end{array}$ & $\begin{array}{c}-0.156 * * * \\
(-5.264) \\
\end{array}$ & $\begin{array}{c}0.002 * * * \\
(4.465) \\
\end{array}$ & $\begin{array}{c}0.000 \\
(0.511) \\
\end{array}$ & $\begin{array}{c}-0.017 * * * \\
(-4.435) \\
\end{array}$ \\
\hline $\begin{array}{l}\text { OTHER BANK CHARACTERISTICS } \\
\text { CRISIS FIXED EFFECTS }\end{array}$ & $\begin{array}{l}\text { YES } \\
\text { YES }\end{array}$ & $\begin{array}{l}\text { YES } \\
\text { YES }\end{array}$ & $\begin{array}{l}\text { YES } \\
\text { YES }\end{array}$ & $\begin{array}{l}\text { YES } \\
\text { YES }\end{array}$ & $\begin{array}{l}\text { YES } \\
\text { YES }\end{array}$ & $\begin{array}{l}\text { YES } \\
\text { YES }\end{array}$ & $\begin{array}{l}\text { YES } \\
\text { YES }\end{array}$ & $\begin{array}{l}\text { YES } \\
\text { YES }\end{array}$ & $\begin{array}{l}\text { YES } \\
\text { YES }\end{array}$ & $\begin{array}{l}\text { YES } \\
\text { YES }\end{array}$ & $\begin{array}{l}\text { YES } \\
\text { YES }\end{array}$ & YES \\
\hline BANK CLUSTERS & YES & YES & YES & YES & YES & YES & YES & YES & YES & YES & YES & YES \\
\hline $\begin{array}{l}\text { NUMBER OF OBSERVATIONS } \\
\text { PSEUDO R }{ }^{2} \text { /ADJ. } \text { R }^{2}\end{array}$ & $\begin{array}{c}48,532 \\
0.289\end{array}$ & $\begin{array}{c}40,067 \\
0.295\end{array}$ & $\begin{array}{c}35,150 \\
0.211\end{array}$ & $\begin{array}{c}35,151 \\
0.101\end{array}$ & $\begin{array}{c}48,532 \\
0.126\end{array}$ & $\begin{array}{c}48,532 \\
0.179\end{array}$ & $\begin{array}{c}48,532 \\
0.312\end{array}$ & $\begin{array}{c}40,067 \\
0.313\end{array}$ & $\begin{array}{c}35,150 \\
0.212\end{array}$ & $\begin{array}{c}35,151 \\
0.102\end{array}$ & $\begin{array}{c}48,532 \\
0.126\end{array}$ & $\begin{array}{c}48,532 \\
0.180\end{array}$ \\
\hline
\end{tabular}




\section{Table 8: Alternative Pre-Crisis Period}

This table reports estimates from regression estimates for analyzing how does cost and profit efficiency during normal times impact bank performance (failure, risk, and profitability) during financial crises when clustering errors at the bank level. The dependent variable for failure are: FAILED1 and FAILED2. The dependent variables for bank risk are: bank $L N(Z S C O R E)$ and $\sigma R O A$. The dependent variables for bank profitability are: $R O A$ and $R O E$. All independent variables are measured as averages over the pre-crisis periods. The key explanatory variables are cost efficiency COSTEFF and profit efficiency PROFITEFF. COST EFF MOMENTUM is the proportion of cost efficiency increases. PROFIT EFF MOMENTUM is the proportion of profit efficiency increases. $L N(G T A)$ is bank size calculated as the natural log of GTA.CAPITAL RATIO is bank capitalization, defined as the bank's total equity divided by GTA. TOTAL LOANS / GTA is the ratio of total loans to GTA. BHC MEMBER is a dummy variable that equals one if the bank was part of a BHC at any time in the pre-crisis period. COMMERCIAL RE RATIO is the commercial real estate loans divided by GTA. SUPERVISOR_OCC and SUPERVISOR_FDIC are dummies that equal 1 if the OCC and FDIC are the primary supervisor of the bank, respectively; both dummies are used in regressions (left out category: SUPERVISOR_FRS). FOREIGN OWNERSHIP is a dummy equal to 1 if a bank has $50 \%$ or more foreign ownership. BROKERED DEPOSITS RATIO is brokered deposits divided by GTA. UNUSED COMMITMENTS RATIO is unused commitments divided by GTA. CASH HOLDINGS RATIO is total bank cash holdings divided by GTA. LLA / GTA is loan loss allowance divided by GTA. HHI DEPOSITS is the bank-level Herfindahl-Hirschman Index (HHI) of deposit concentration for the local markets in which the bank is present. PERCENT METROPOLITAN is the percentage of bank deposits in metropolitan markets (MSAs and CBSAs) as a fraction of deposits in all markets in which a bank is active. BRANCHES / GTA is a measure of bank organizational complexity calculated as (ratio of the number of branches the bank has active over GTA) x 1000. LN (NUMBER STATES) is the natural log of the number of states in which bank has branches. PUBLICLY LISTED is a dummy equal to 1 if a bank is listed or is part of a BHC that is listed on a stock exchange. CHANGE COINCIDENT INDEX is the weighted average of the changes in the Philadelphia Federal Reserve's state coincident indexes with the share of the deposits of a given bank taken as weights. HOUSE PRICE INFLATION is the weighted average growth in a state-level house price index with the share of the deposits of a given bank taken as weights. LOAN CONCENTRATION is a bank's loan portfolio concentration is measured as a Herfindahl-Hirschman Index (HHI) of the following six loan categories: commercial real estate, residential real estate, construction and industrial, consumer, agriculture, and other loans. All variables are defined in Table 1. Robust $t$-statistics adjusted for bank clustering are reported in parentheses. *,**, and $* * *$ denote significance at $10 \%, 5 \%$, and $1 \%$ level.

\begin{tabular}{|c|c|c|c|c|c|c|}
\hline \multirow[b]{2}{*}{ Performance Indicator } & (1) & (2) & (3) & (4) & (5) & (6) \\
\hline & \multicolumn{2}{|c|}{ FAILURE } & \multicolumn{2}{|c|}{ RISK } & \multicolumn{2}{|c|}{ PROFITABILITY } \\
\hline Dependent Variable & FAILED1 & FAILED2 & LN(ZSCORE) & $\sigma R O A$ & $R O A$ & $R O E$ \\
\hline Independent Variables \& Regression Method & LOGIT & LOGIT & OLS & OLS & OLS & OLS \\
\hline \multicolumn{7}{|c|}{ Key Independent Variables and Basic Characteristics } \\
\hline $\begin{array}{l}\text { COST EFF MOMENTUM } \\
\text { PROFIT EFF MOMENTUM }\end{array}$ & $\begin{array}{c}-1.380 * * * \\
(-8.049) \\
-0.439 * * * \\
(-2.599)\end{array}$ & $\begin{array}{c}-2.583 * * * \\
(-12.069) \\
-0.553 * * \\
(-2.400)\end{array}$ & $\begin{array}{c}0.277 * * * \\
(11.324) \\
-0.002 \\
(-0.083) \\
\end{array}$ & $\begin{array}{c}-0.002 * * * \\
(-7.923) \\
-0.000 \\
(-0.088)\end{array}$ & $\begin{array}{c}0.003 * * * \\
(9.674) \\
0.001 * \\
(1.923)\end{array}$ & $\begin{array}{c}0.028 * * * \\
(10.531) \\
0.007 * * \\
(2.054)\end{array}$ \\
\hline $\begin{array}{l}\text { OTHER BANK CHARACTERISTICS } \\
\text { CRISIS FIXED EFFECTS } \\
\text { BANK CLUSTERS }\end{array}$ & $\begin{array}{l}\text { YES } \\
\text { YES } \\
\text { YES }\end{array}$ & $\begin{array}{l}\text { YES } \\
\text { YES } \\
\text { YES }\end{array}$ & $\begin{array}{l}\text { YES } \\
\text { YES } \\
\text { YES }\end{array}$ & $\begin{array}{l}\text { YES } \\
\text { YES } \\
\text { YES }\end{array}$ & $\begin{array}{l}\text { YES } \\
\text { YES } \\
\text { YES }\end{array}$ & $\begin{array}{l}\text { YES } \\
\text { YES } \\
\text { YES }\end{array}$ \\
\hline $\begin{array}{l}\text { NUMBER OF OBSERVATIONS } \\
\text { PSEUDO R }^{2} / \text { ADJ. } \text { R }^{2}\end{array}$ & $\begin{array}{c}48,532 \\
0.289 \\
\end{array}$ & $\begin{array}{c}40,067 \\
0.292 \\
\end{array}$ & $\begin{array}{c}35,150 \\
0.211 \\
\end{array}$ & $\begin{array}{c}35,151 \\
0.101 \\
\end{array}$ & $\begin{array}{c}48,532 \\
0.126 \\
\end{array}$ & $\begin{array}{c}48,532 \\
0.179 \\
\end{array}$ \\
\hline
\end{tabular}


Table 9: Do Cost and Profit Efficiency Affect Bank Failure, Risk, and Profitability during Financial Crises? - Bank Size

This table reports estimates from regression estimates for analyzing how does cost and profit efficiency during normal times impact bank performance (failure, risk, and profitability) during financial crises when clustering errors at the bank level. The dependent variable for failure are: FAILED1 and FAILED2. The dependent variables for bank risk are: bank $L N(Z S C O R E)$ and $\sigma R O A$. The dependent variables for bank profitability are: $R O A$ and $R O E$. All independent variables are measured as averages over the pre-crisis periods. The key explanatory variables are cost efficiency COSTEFF and profit efficiency PROFITEFF. COST EFF MOMENTUM is the proportion of cost efficiency increases. PROFIT EFF MOMENTUM is the proportion of profit efficiency increases. $L N(G T A)$ is bank size calculated as the natural log of GTA.CAPITAL RATIO is bank capitalization, defined as the bank's total equity divided by GTA. TOTAL LOANS / GTA is the ratio of total loans to GTA. BHC MEMBER is a dummy variable that equals one if the bank was part of a BHC at any time in the pre-crisis period. COMMERCIAL RE RATIO is the commercial real estate loans divided by GTA. SUPERVISOR_OCC and SUPERVISOR_FDIC are dummies that equal 1 if the OCC and FDIC are the primary supervisor of the bank, respectively; both dummies are used in regressions (left out category: SUPERVISOR_FRS). FOREIGN OWNERSHIP is a dummy equal to 1 if a bank has $50 \%$ or more foreign ownership. BROKERED DEPOSITS RATIO is brokered deposits divided by GTA. UNUSED COMMITMENTS RATIO is unused commitments divided by GTA. CASH HOLDINGS RATIO is total bank cash holdings divided by GTA. LLA / GTA is loan loss allowance divided by GTA. HHI DEPOSITS is the bank-level Herfindahl-Hirschman Index (HHI) of deposit concentration for the local markets in which the bank is present. PERCENT METROPOLITAN is the percentage of bank deposits in metropolitan markets (MSAs and CBSAs) as a fraction of deposits in all markets in which a bank is active. BRANCHES / GTA is a measure of bank organizational complexity calculated as (ratio of the number of branches the bank has active over GTA) x 1000. LN (NUMBER STATES) is the natural log of the number of states in which bank has branches. PUBLICLY LISTED is a dummy equal to 1 if a bank is listed or is part of a BHC that is listed on a stock exchange. CHANGE COINCIDENT INDEX is the weighted average of the changes in the Philadelphia Federal Reserve's state coincident indexes with the share of the deposits of a given bank taken as weights. HOUSE PRICE INFLATION is the weighted average growth in a state-level house price index with the share of the deposits of a given bank taken as weights. LOAN CONCENTRATION is a bank's loan portfolio concentration is measured as a Herfindahl-Hirschman Index (HHI) of the following six loan categories: commercial real estate, residential real estate, construction and industrial, consumer, agriculture, and other loans. All variables are defined in Table 1. Robust $t$-statistics adjusted for bank clustering are reported in parentheses. *, **, and $* * *$ denote significance at $10 \%, 5 \%$, and $1 \%$ level.

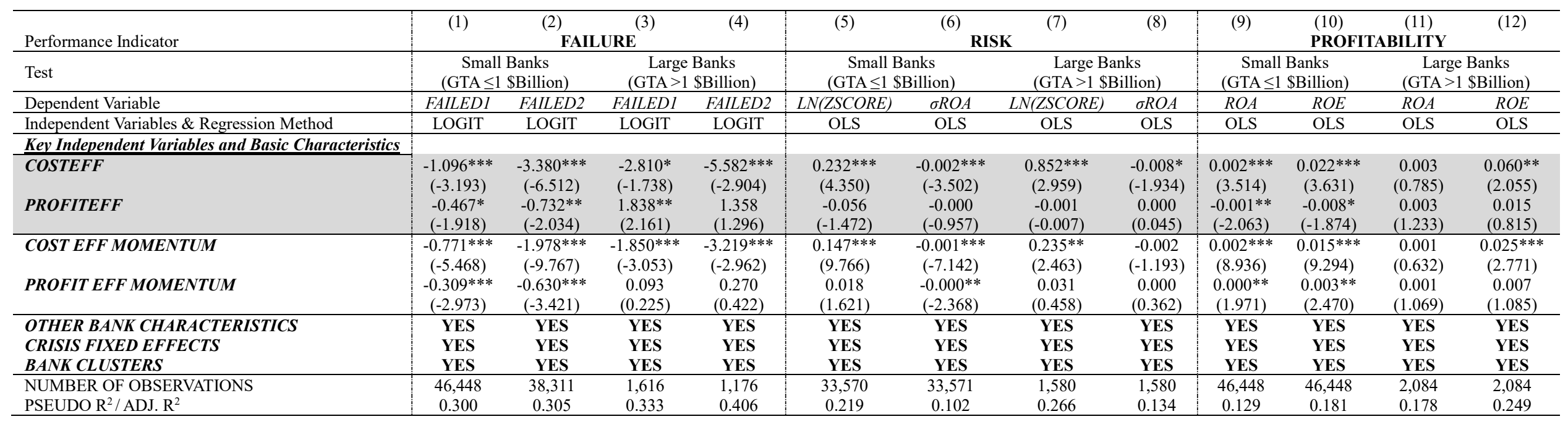


Table 10: Do Cost and Profit Efficiency Affect Bank Failure, Risk, and Profitability during Financial Crises? - Testing for Non-Monotonicity This table reports estimates from regression estimates for analyzing how does cost and profit efficiency during normal times impact bank performance (failure, risk, and profitability) during financial crises when testing for non-monotonicity between efficiency and bank performance. The dependent variable for failure are: FAILED1 and FAILED2. The dependent variables for bank risk are: bank $L N(Z S C O R E)$ and $\sigma R O A$. The dependent variables for bank profitability are: ROA and ROE. All independent variables are measured as averages over the pre-crisis periods. The key explanatory variables are cost efficiency COSTEFF and profit efficiency PROFITEFF. COST EFF MOMENTUM is the proportion of cost efficiency increases. PROFIT EFF MOMENTUM is the proportion of profit efficiency increases. $L N(G T A)$ is bank size calculated as the natural $\log$ of GTA.CAPITAL RATIO is bank capitalization, defined as the bank's total equity divided by GTA. TOTAL LOANS / GTA is the ratio of total loans to GTA. BHC MEMBER is a dummy variable that equals one if the bank was part of a BHC at any time in the precrisis period. COMMERCIAL RE RATIO is the commercial real estate loans divided by GTA. SUPERVISOR OCC and SUPERVISOR FDIC are dummies that equal 1 if the OCC and FDIC are the primary supervisor of the bank, respectively; both dummies are used in regressions (left out category: SUPERVISOR_FRS). FOREIGN OWNERSHIP is a dummy equal to 1 if a bank has $50 \%$ or more foreign ownership. BROKERED DEPOSITS RATIO is brokered deposits divided by GTA. UNUSED COMMITMENTS RATIO is unused commitments divided by GTA. CASH HOLDINGS RATIO is total bank cash holdings divided by GTA. LLA / GTA is loan loss allowance divided by GTA. HHI DEPOSITS is the bank-level Herfindahl-Hirschman Index (HHI) of deposit concentration for the local markets in which the bank is present. PERCENT METROPOLITAN is the percentage of bank deposits in metropolitan markets (MSAs and CBSAs) as a fraction of deposits in all markets in which a bank is active. BRANCHES / GTA is a measure of bank organizational complexity calculated as (ratio of the number of branches the bank has active over GTA) x 1000. LN (NUMBER STATES) is the natural log of the number of states in which bank has branches. PUBLICLY LISTED is a dummy equal to 1 if a bank is listed or is part of a BHC that is listed on a stock exchange. CHANGE COINCIDENT INDEX is the weighted average of the changes in the Philadelphia Federal Reserve's state coincident indexes with the share of the deposits of a given bank taken as weights. HOUSE PRICE INFLATION is the weighted average growth in a state-level house price index with the share of the deposits of a given bank taken as weights. LOAN CONCENTRATION is a bank's loan portfolio concentration is measured as a Herfindahl-Hirschman Index (HHI) of the following six loan categories: commercial real estate, residential real estate, construction and industrial, consumer, agriculture, and other loans. All variables are defined in Table 1. Robust $t$-statistics adjusted for bank clustering are reported in parentheses. *, **, and *** denote significance at $10 \%, 5 \%$, and $1 \%$ level.

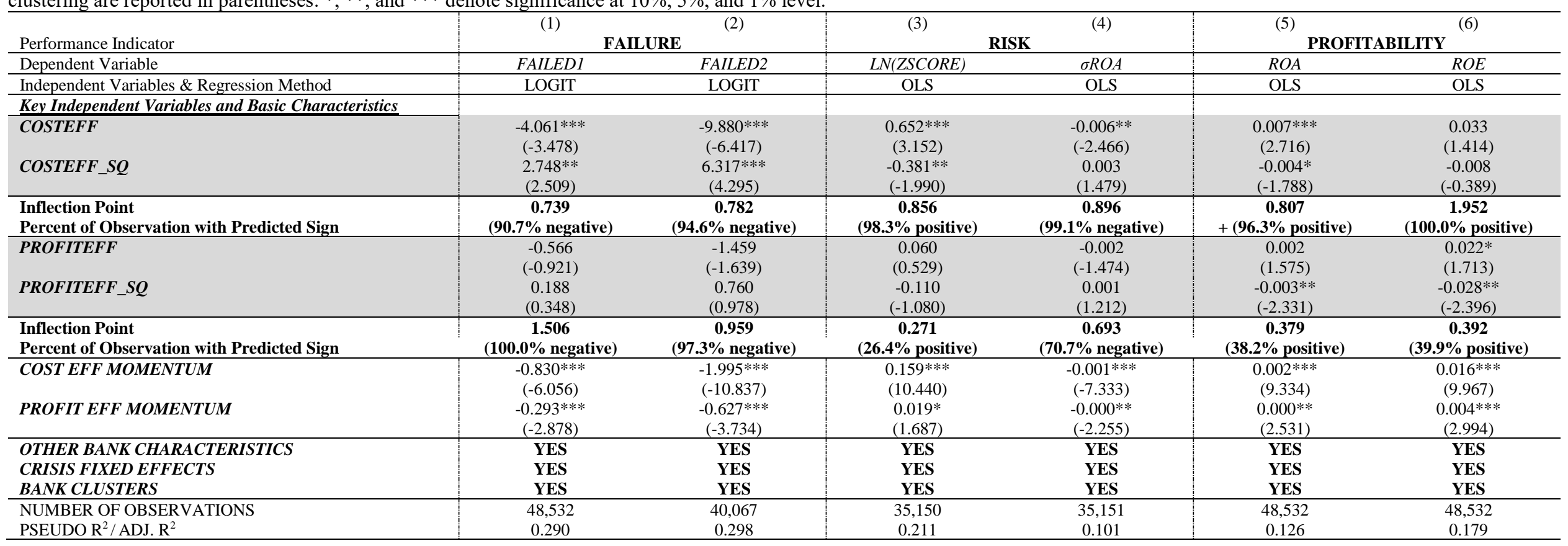


Table 11: Deeper Analysis of the Cost Efficiency Findings

This table reports estimates from regression estimates for analyzing how does cost and profit efficiency during normal times impact bank performance (failure, risk and profitability) for banks with Good Management (Enforcement Actions against Management $=0$ ) versus banks with Bad Management (Enforcement Actions against Management $>0$ ) in columns (1)-(12), and how cost and profit efficiency during normal times affect bank loan performance (NPL/TL and $L L A / G T A$ ) during financial crises in columns (13)-(14). The dependent variable for failure are FAILED1 and FAILED2. The dependent variables for bank risk are: bank LN(ZSCORE) and $\sigma R O A$. The dependent variables for bank profitability are: ROA and ROE. All independent variables are measured as averages over the pre-crisis periods. The key explanatory variables are cost efficiency COSTEFF and profit efficiency PROFITEFF. COST EFF MOMENTUM is the proportion of cost efficiency increases. PROFIT EFF MOMENTUM is the proportion of profit efficiency increases. LN(GTA) is bank size calculated as the natural log of GTA.CAPITAL RATIO is bank capitalization, defined as the bank's total equity divided by GTA. TOTAL LOANS / GTA is the ratio of total loans to GTA. BHC MEMBER is a dummy variable that equals one if the bank was part of a BHC at any time in the pre-crisis period. COMMERCIAL RE RATIO is the commercial real estate loans divided by GTA. SUPERVISOR_OCC and SUPERVISOR_FDIC are dummies that equal 1 if the OCC and FDIC are the primary supervisor of the bank, respectively; both dummies are used in regressions (left out category: SUPERVISOR_FRS). FOREIGN OWNERSHIP is a dummy equal to 1 if a bank has 50\% or more foreign ownership. BROKERED DEPOSITS RATIO is brokered deposits divided by GTA. UNUSED COMMITMENTS RATIO is unused commitments divided by GTA. CASH HOLDINGS RATIO is total bank cash holdings divided by GTA. LLA / GTA is loan loss allowance divided by GTA. HHI DEPOSITS is the bank-level Herfindahl-Hirschman Index (HHI) of deposit concentration for the local markets in which the bank is present. PERCENT METROPOLITAN is the percentage of bank deposits in metropolitan markets (MSAs and CBSAs) as a fraction of deposits in all markets in which a bank is active. BRANCHES / GTA is a measure of bank organizational complexity calculated as (ratio of the number of branches the bank has active over GTA) $x 1000 . L N$ (NUMBER STATES) is the natural log of the number of states in which bank has branches. PUBLICLY LISTED is a dummy equal to 1 if a bank is listed or is part of a BHC that is listed on a stock exchange. CHANGE COINCIDENT INDEX is the weighted average of the changes in the Philadelphia Federal Reserve's state coincident indexes with the share of the deposits of a given bank taken as weights. HOUSE PRICE INFLATION is the weighted average growth in a state-level house price index with the share of the deposits of a given bank taken as weights. LOAN CONCENTRATION is a bank's loan portfolio concentration is measured as a Herfindahl-Hirschman Index (HHI) of the following six loan categories: commercial real estate, residential real estate, construction and industrial, consumer, agriculture, and other loans. All variables are defined in Table 1. Robust $t$-statistics adjusted for bank clustering are reported in parentheses. *,**, and *** denote significance at $10 \%, 5 \%$, and $1 \%$ level.

\begin{tabular}{|c|c|c|c|c|c|c|c|c|c|c|c|c|c|c|}
\hline & (1) & (2) & (3) & (4) & (5) & (6) & (7) & (8) & (9) & (10) & (11) & (12) & (13) & (14) \\
\hline Performance Indicator & \multicolumn{4}{|c|}{ FAILURE } & \multicolumn{4}{|c|}{ RISK } & \multicolumn{4}{|c|}{ PROFITABILITY } & \multicolumn{2}{|c|}{ OTHER MEASURES } \\
\hline Subsample & \multicolumn{2}{|c|}{$\begin{array}{l}\text { Good Management } \\
\text { (Enforcement Actions } \\
\text { against Management } \\
=0 \text { ) }\end{array}$} & \multicolumn{2}{|c|}{$\begin{array}{c}\text { Bad Management } \\
\text { (Enforcement Actions } \\
\text { against Management } \\
>0 \text { ) }\end{array}$} & \multicolumn{2}{|c|}{$\begin{array}{l}\text { Good Management } \\
\text { (Enforcement Actions } \\
\text { against Management } \\
=0 \text { ) }\end{array}$} & \multicolumn{2}{|c|}{$\begin{array}{c}\text { Bad Management } \\
\text { (Enforcement Actions } \\
\text { against Management } \\
>0 \text { ) }\end{array}$} & \multicolumn{2}{|c|}{$\begin{array}{l}\text { Good Management } \\
\text { (Enforcement Actions } \\
\text { against Management } \\
=0 \text { ) }\end{array}$} & \multicolumn{2}{|c|}{$\begin{array}{c}\text { Bad Management } \\
\text { (Enforcement } \\
\text { Actions } \\
\text { against Management } \\
>0 \text { ) } \\
\end{array}$} & \multicolumn{2}{|c|}{$\begin{array}{l}\text { Testing } \\
\text { the Cost } \\
\text { Skimping } \\
\text { Hypothesis }\end{array}$} \\
\hline Dependent Variable & FAILEDI & FAILED2 & FAILEDI & FAILED2 & LN(ZSCORE) & $\sigma R O A$ & $L N(Z S C O R E)$ & $\sigma R O A$ & $R O A$ & ROE & $R O A$ & $R O E$ & $N P L$ & LLA \\
\hline Independent Variables \& Regression Method & LOGIT & LOGIT & LOGIT & LOGIT & OLS & OLS & OLS & OLS & OLS & OLS & OLS & OLS & OLS & OLS \\
\hline \multicolumn{15}{|c|}{ Key Independent Variables and Basic Characteristics } \\
\hline COSTEFF & $\begin{array}{c}-1.215 * * * \\
(-3.548)\end{array}$ & $\begin{array}{c}-3.562 * * * \\
(-6.925)\end{array}$ & $\begin{array}{c}2.013 \\
(0.593)\end{array}$ & $\begin{array}{c}6.085 \\
(1.137)\end{array}$ & $\begin{array}{c}0.254 * * * * \\
(4.765)\end{array}$ & $\begin{array}{c}-0.003 * * * \\
(-3.846)\end{array}$ & $\begin{array}{c}0.436 \\
(0.697)\end{array}$ & $\begin{array}{c}-0.006 \\
(-0.591)\end{array}$ & $\begin{array}{c}0.002 * * * \\
(3.701)\end{array}$ & $\begin{array}{c}0.024 * * * \\
(4.055)\end{array}$ & $\begin{array}{c}-0.007 \\
(-1.083)\end{array}$ & $\begin{array}{c}-0.075 \\
(-1.350)\end{array}$ & $\begin{array}{c}-0.002 * * * \\
(-2.739)\end{array}$ & $\begin{array}{c}-0.0003 * * \\
(-2.016)\end{array}$ \\
\hline COST EFF MOMENTUM & $\begin{array}{c}-0.816 * * * * \\
(-5.739)\end{array}$ & $\begin{array}{c}-2.111 * * * \\
(-10.030)\end{array}$ & $\begin{array}{c}1.315 \\
(0.492)\end{array}$ & $\begin{array}{c}4.499 \\
(1.285)\end{array}$ & $\begin{array}{c}0.155 * * * \\
(10.316)\end{array}$ & $\begin{array}{c}-0.001 * * * * \\
(-7.289)\end{array}$ & $\begin{array}{c}0.237 \\
(0.530)\end{array}$ & $\begin{array}{c}-0.002 \\
(-0.344)\end{array}$ & $\begin{array}{c}0.002 * * * \\
(9.194)\end{array}$ & $\begin{array}{c}0.016 * * * * \\
(10.032)\end{array}$ & $\begin{array}{c}-0.006 \\
(-1.421)\end{array}$ & $\begin{array}{c}-0.070 \\
(-1.615)\end{array}$ & $\begin{array}{c}-0.001 * * * \\
(-4.313)\end{array}$ & $\begin{array}{c}-0.0002 \text { **** } \\
(-4.882)\end{array}$ \\
\hline PROFIT EFF MOMENTUM & $\begin{array}{c}-0.283 * * * * \\
(-2.761) \\
\end{array}$ & $\begin{array}{c}-0.572 * * * \\
(-3.202) \\
\end{array}$ & $\begin{array}{c}-0.340 \\
(-0.308) \\
\end{array}$ & $\begin{array}{c}-0.535 \\
(-0.357) \\
\end{array}$ & $\begin{array}{r}0.017 \\
(1.527) \\
\end{array}$ & $\begin{array}{c}-0.000 * * \\
(-2.128) \\
\end{array}$ & $\begin{array}{l}-0.361 * \\
(-1.665) \\
\end{array}$ & $\begin{array}{c}0.002 \\
(0.563) \\
\end{array}$ & $\begin{array}{c}0.000 * * \\
(2.173) \\
\end{array}$ & $\begin{array}{l}0.003 * * \\
(2.574)\end{array}$ & $\begin{array}{c}-0.001 \\
(-0.572) \\
\end{array}$ & $\begin{array}{c}-0.002 \\
(-0.093) \\
\end{array}$ & $\begin{array}{l}-0.000 * \\
(-1.653) \\
\end{array}$ & $\begin{array}{r}0.0000 \\
(0.068) \\
\end{array}$ \\
\hline OTHER BANK CHARACTERISTICS & YES & YES & YES & YES & YES & YES & YES & YES & YES & YES & YES & YES & YES & YES \\
\hline CRISIS FIXED EFFECTS & YES & YES & YES & YES & YES & YES & YES & YES & YES & YES & YES & YES & YES & YES \\
\hline BANK CLUSTERS & YES & YES & YES & YES & YES & YES & YES & YES & YES & YES & YES & YES & YES & YES \\
\hline NUMBER OF OBSERVATIONS & 47,654 & 39,477 & 856 & 576 & 34,291 & 34,292 & 859 & 859 & 47,654 & 47,654 & 878 & 878 & 48,532 & 48,532 \\
\hline PSEUDO R $/$ ADJ. R ${ }^{2}$ & 0.297 & 0.303 & 0.283 & 0.343 & 0.212 & 0.101 & 0.222 & 0.151 & 0.127 & 0.181 & 0.092 & 0.147 & 0.246 & 0.526 \\
\hline
\end{tabular}

